\title{
MicroRNAs, Long Non-Coding RNAs, and Circular RNAs in the Redox Control of Cell Senescence
}

\author{
Daniele Lettieri-Barbato ${ }^{1,2}$, Katia Aquilano ${ }^{1}$ (D) Carolina Punziano ${ }^{3}$, Giuseppina Minopoli ${ }^{3}$ \\ and Raffaella Faraonio $3, *$ (D)
}

1 Department of Biology, University of Rome Tor Vergata, 00133 Rome, Italy; daniele.lettieri.barbato@uniroma2.it (D.L.-B.); katia.aquilano@uniroma2.it (K.A.)

2 IRCCS Santa Lucia, 00179 Rome, Italy

3 Department of Molecular Medicine and Medical Biotechnologies, University of Naples Federico II, 80131 Naples, Italy; carolina.punziano@unina.it (C.P.); giuseppina.minopoli@unina.it (G.M.)

* Correspondence: raffaella.faraonio@unina.it; Tel.: +39-0817463642

Citation: Lettieri-Barbato, D.; Aquilano, K.; Punziano, C.; Minopoli, G.; Faraonio, R. MicroRNAs, Long Non-Coding RNAs, and Circular RNAs in the Redox Control of Cell Senescence. Antioxidants 2022, 11, 480. https://doi.org/10.3390/antiox 11030480

Academic Editor: Consuelo Borras

Received: 19 January 2022

Accepted: 24 February 2022

Published: 28 February 2022

Publisher's Note: MDPI stays neutral with regard to jurisdictional claims in published maps and institutional affiliations.

Copyright: (c) 2022 by the authors. Licensee MDPI, Basel, Switzerland. This article is an open access article distributed under the terms and conditions of the Creative Commons Attribution (CC BY) license (https:// creativecommons.org/licenses/by/ $4.0 /)$.

\begin{abstract}
Cell senescence is critical in diverse aspects of organism life. It is involved in tissue development and homeostasis, as well as in tumor suppression. Consequently, it is tightly integrated with basic physiological processes during life. On the other hand, senescence is gradually being considered as a major contributor of organismal aging and age-related diseases. Increased oxidative stress is one of the main risk factors for cellular damages, and thus a driver of senescence. In fact, there is an intimate link between cell senescence and response to different types of cellular stress. Oxidative stress occurs when the production of reactive oxygen species/reactive nitrogen species (ROS/RNS) is not adequately detoxified by the antioxidant defense systems. Non-coding RNAs are endogenous transcripts that govern gene regulatory networks, thus impacting both physiological and pathological events. Among these molecules, microRNAs, long non-coding RNAs, and more recently circular RNAs are considered crucial mediators of almost all cellular processes, including those implicated in oxidative stress responses. Here, we will describe recent data on the link between ROS/RNS-induced senescence and the current knowledge on the role of non-coding RNAs in the senescence program.
\end{abstract}

Keywords: cell senescence; oxidative stress; redox homeostasis; aging; non-coding RNAs; microRNAs; long non-coding RNAs; circular RNAs

\section{Introduction}

It is now established that cell senescence plays an increasingly significant role than first envisaged in the physio-pathology of the organism with already recognized beneficial and detrimental effects [1]. First, during embryogenesis, senescence has an active role in the normal development of different tissues [2,3]. Second, senescence controls tissue repair and homeostasis [4]. Third, senescence-induced cell cycle arrest can suppress tumor growth [5-8] and activate the clearance of tumor cells [9]. On the other hand, the accumulation of senescent cells during life may foster the onset of aging [10,11] and age-related pathologies, such as neurodegenerative diseases [12], cardiovascular pathologies [13], metabolic disorders [14], and eventually promote cancer [15-17]. Therefore, senescence has been proposed as a possible target to treat aging-related diseases and delay the aging process [18-20].

Endogenous reactive oxygen species (ROS) and reactive nitrogen species (RNS) are generated due to the aerobic metabolism or produced by specific enzymes, as well as following extracellular stimuli (recently reviewed in [21-23]). At physiological levels, ROS/RNS can fulfill important proliferative cascades and function as signal molecules [21,22,24]. However, due to their reactivity/toxicity, elevated ROS/RNS amounts trigger the accumulation of oxidative damages in the biomolecules, which are intercepted by endogenous 
sensors engaging downstream pathways to evoke a premature senescence program [25-27]. Senescent cells implement ROS/RNS production, which can in turn, enforce the proliferative arrest with further inadequate responses/effects [25,28,29].

There are multiple levels of regulation in the signaling network(s) initiating the cellular senescence program and sustaining it once activated. Most of these are based on transcriptional and posttranscriptional, as well as epigenetic changes highlighting not only proteins, but also different types of RNAs, including non-coding RNAs (ncRNAs), as crucial components of cell senescence program [27,30-33]. Non-coding RNAs constitute the majority of endogenous transcripts in the cells and comprise numerous RNA species grouped in different classes, based on their different lengths and activities. A well-known class includes "housekeeping" ncRNAs, such as ribosomal, transfer, and small nuclear/nucleolar RNAs with prominent roles in general cell functions. Another class comprises "regulatory" ncRNAs that groups RNA molecules with specific functions linked to the regulation of gene expression [33,34]. Among regulatory ncRNAs, microRNAs (miRNAs), long non-coding RNAs (lncRNAs), and more recently circular RNAs (circRNAs) [35-38] have been shown to play important roles in the physiopathology of organism cell senescence. Furthermore, ncRNAs are highly responsive to specific stimuli, which are involved in different cellular responses, including those evoked by oxidative stress [37], such as cell senescence.

The aim of the present review is to summarize the recent studies on the impact of miRNAs, lncRNAs, and circRNAs, as well as their regulatory integrated networks in cell senescence with particular attention to their functions in oxidative stress-induced senescence.

\section{Cell Senescence as an Active Biological Program}

Forty years ago, Dr. Leonard Hayflick provided the first evidence that primary human cells had a limited replicative capacity in culture (often referred to as the "Hayflick Limit") [39]. The major determinant of this phenomenon, termed replicative senescence, is the length of telomeres [40]. Cells sense short telomeres as unresolved DNA damage and develop a double-strand DNA break response that irreversibly arrests proliferation [41,42]. However, telomere shortening is not the only cause of cell senescence. In fact, cell senescence is rapidly elicited in response to different types of stressors, such as increased oxidative stress $[25,26,43,44]$, mitochondrial dysfunctions [45,46], aberrant oncogene activation [47-49], ionizing/ultraviolet radiations [50,51], epigenetic and chromatin perturbations [52], chemotherapeutic drugs [53], and altered translation process [54] (Figure 1). Of note, most of the senescence-inducing stimuli have been associated to ROS/RNS increase $[28,55,56]$. These intrinsic and/or extrinsic insults could directly or indirectly engage a DNA damage response (DDR) (reviewed in [42,57-59]). Therefore, cells halt proliferation and become prematurely senescent (premature or stress-induced senescence).

Despite their inability to replicate, senescent cells acquire specific features, such as morphological changes, metabolic and transcriptional reprogramming, as well as chromatin reorganization $[27,60,61]$. More importantly, they also express the so-called senescenceassociated secretory phenotype (SASP) containing inflammatory chemokines and cytokines, growth factors, and proteases [62-64]. Of note, the SASP is cell type specific and can drive both physiological and pathological effects on local and/or distal tissues during life (reviewed in $[20,27,59,65,66]$ ).

Senescent cells are resistant to different apoptotic stimuli, mainly due to the increased expression of BCL-2 family proteins, such as BCL-W and BCL-XL [67]. Therefore, they are not eliminated, but rather accumulate in the organism, further sustaining redox imbalance, SASP and/or secretion of extracellular vesicles that also support non-autonomous activities $[25,28,68]$. Additionally, senescent cells exhibit resistance to ferroptosis, a nonapoptotic, iron-dependent form of cell death [69]. Increased iron in senescent cells could foster ROS/RNS increase and has been proposed as a new hallmark of senescence $[25,28,70]$.

Even if senescence is a physiological response, widely recognized as an intrinsic tumor suppressor mechanism [48], a crucial contributor to embryonic morphogenesis [2,3] and 
to tissue repair [71-73], it is increasingly considered an important factor in aging and age-related pathologies (reviewed in $[27,74]$ ). Senescence has been observed both in mitotic and post-mitotic cells, as well as in adult stem cell pools of different tissues. Therefore, the accumulation of senescent cells impacts on the functionality of organs and limits also tissue renewal in vivo $[27,74,75]$. Importantly, senescence of mesenchymal stem cells (MSCs), now defined as mesenchymal stromal cells (MSCs), hinders their regenerative therapeutic potential [76].

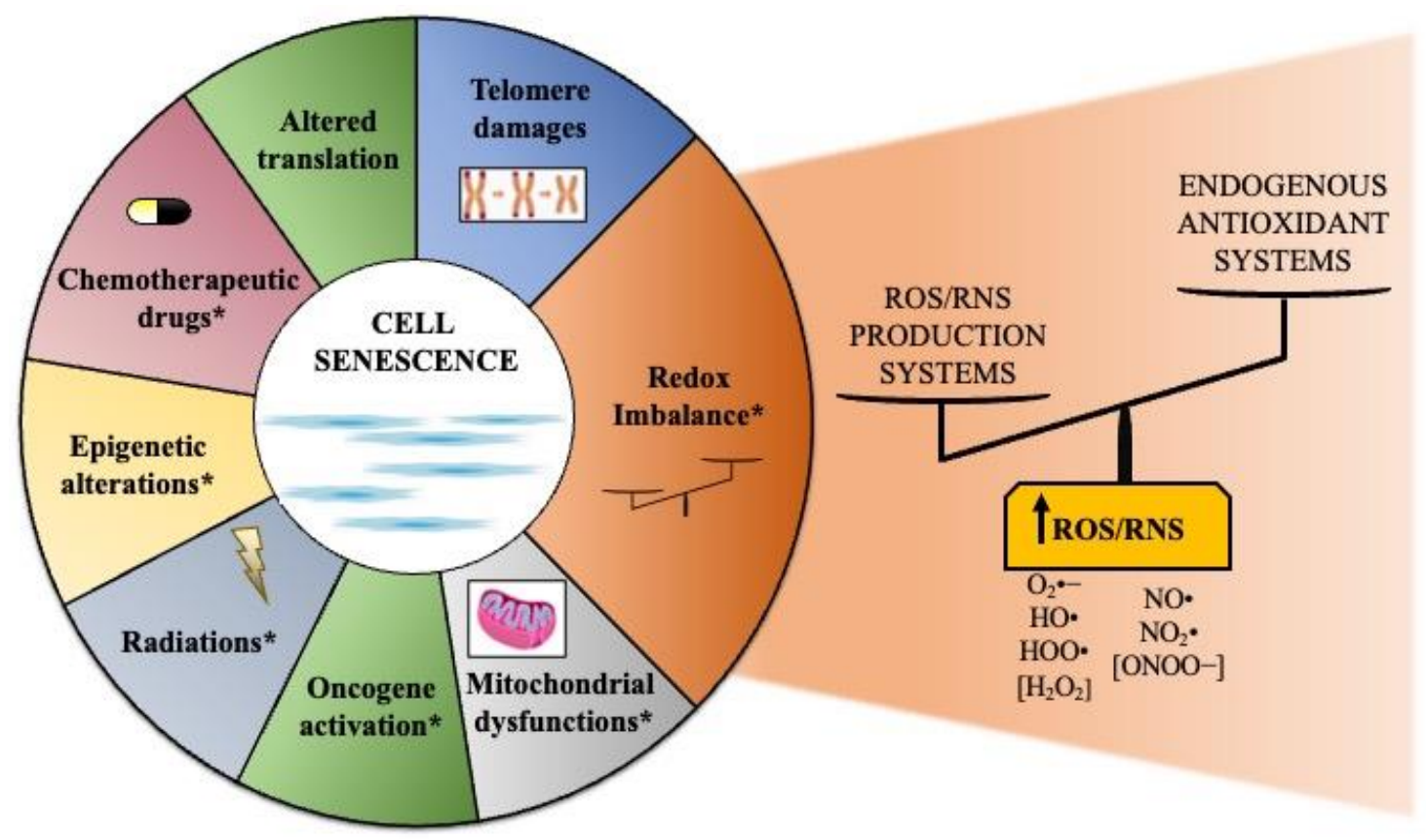

Figure 1. Intrinsic and extrinsic causes of cellular senescence. Schematic diagram showing the major inducers of cellular senescence. Damages to telomeres, redox imbalance, mitochondrial dysfunctions, activation of oncogenes, ionizing/ultraviolet radiations, epigenetic and chromatin alterations, chemotherapeutic drugs, and altered translation can promote the senescence program. Redox imbalance can be generated by decreased endogenous antioxidant defenses or increased ROS/RNS production. The main ROS/RNS are reported (the non-radical species are indicated in parenthesis). Most of these senescence inducers act by releasing ROS/RNS or by increasing ROS/RNS production. ROS/RNS can directly affect telomere integrity and cause altered translation process. * indicates senescence inducers that release or increase ROS/RNS.

\section{Cell Senescence: A Focus on ROS/RNS-Mediated Pathways}

The "oxidative stress theory of aging" postulates that cumulative oxidative damages to biomolecules, caused by "a disturbance in the prooxidant-antioxidant balance in favor of the former", are responsible for the natural ageing process and that this can foster age-related pathological processes $[77,78]$. Despite the introduction of the concept of cell response to redox imbalance and recognizing a primary role of ROS/RNS in physiopathological decline, this theory has gradually changed $[79,80]$. The next sections briefly discuss data linking oxidative stress to senescence.

\subsection{Redox Homeostasis and Antioxidant Systems: Links to Senescence}

Indeed, the term "Redox Homeostasis" encompasses a dynamic concept: Endogenous ROS/RNS, when produced in a regulated manner, are essential signaling molecules conferring outputs for living organisms, and thus their levels are finely regulated under physiological conditions $[23,24,81]$. On the one hand, this implicates that cells preserve physiological levels of ROS/RNS as normal oxidant cues (called eustress). On the other hand, cells neutralize ROS/RNS through intracellular defense systems to avoid oxidative 
challenges (termed distress) [21,82]. In fact, senescent cells fail to balance their intracellular redox status, skewing towards increased ROS/RNS that fuel senescence signaling and stabilization $[25,28,29,83,84]$.

\subsubsection{ROS and RNS Generation and Cell Senescence}

ROS and RNS are highly reactive molecules comprising free radicals and non-radical species (reviewed in $[21,23,83,85]$ ). ROS include the superoxide anion $\left(\mathrm{O}_{2}{ }^{\bullet-}\right.$ ), the hydroxyl $\left(\mathrm{HO}^{\bullet}\right)$, and the hydroperoxyl $\left(\mathrm{H} / \mathrm{ROO}^{\bullet}\right)$ radicals, as well as the non-radical hydrogen peroxide $\left(\mathrm{H}_{2} \mathrm{O}_{2}\right)$. They can originate as byproducts of the aerobic metabolism inside the mitochondrial electron transport chain (ETC) or from dedicated enzymatic reactions, as well as directly through the Fenton reactions (reviewed in [85-87]) (Figure 2). $\mathrm{H}_{2} \mathrm{O}_{2}$ represents the most relevant ROS: With a relatively low reactivity, it is the main component of signaling cascades and its principal targets are the thiol of cysteine residues, leading to changes in protein activities, as excellently reviewed elsewhere [21,88]. Moreover, $\mathrm{H}_{2} \mathrm{O}_{2}$ is regarded as the main source of $\mathrm{HO}^{\bullet}$, which is the most reactive ROS provoking non-enzymatic oxidation in all of the biomolecules [21,89]. The prevalent RNS include the nitric oxide $\left(\mathrm{NO}^{\bullet}\right)$, produced by nitric oxide synthase (NOS) enzymes, the radical nitrogen dioxide $\left(\mathrm{NO}_{2}^{\bullet}\right)$, and the highly genotoxic peroxynitrite anion $\left(\mathrm{ONOO}^{-}\right)[23,85,86,89-91]$ (Figure 2).
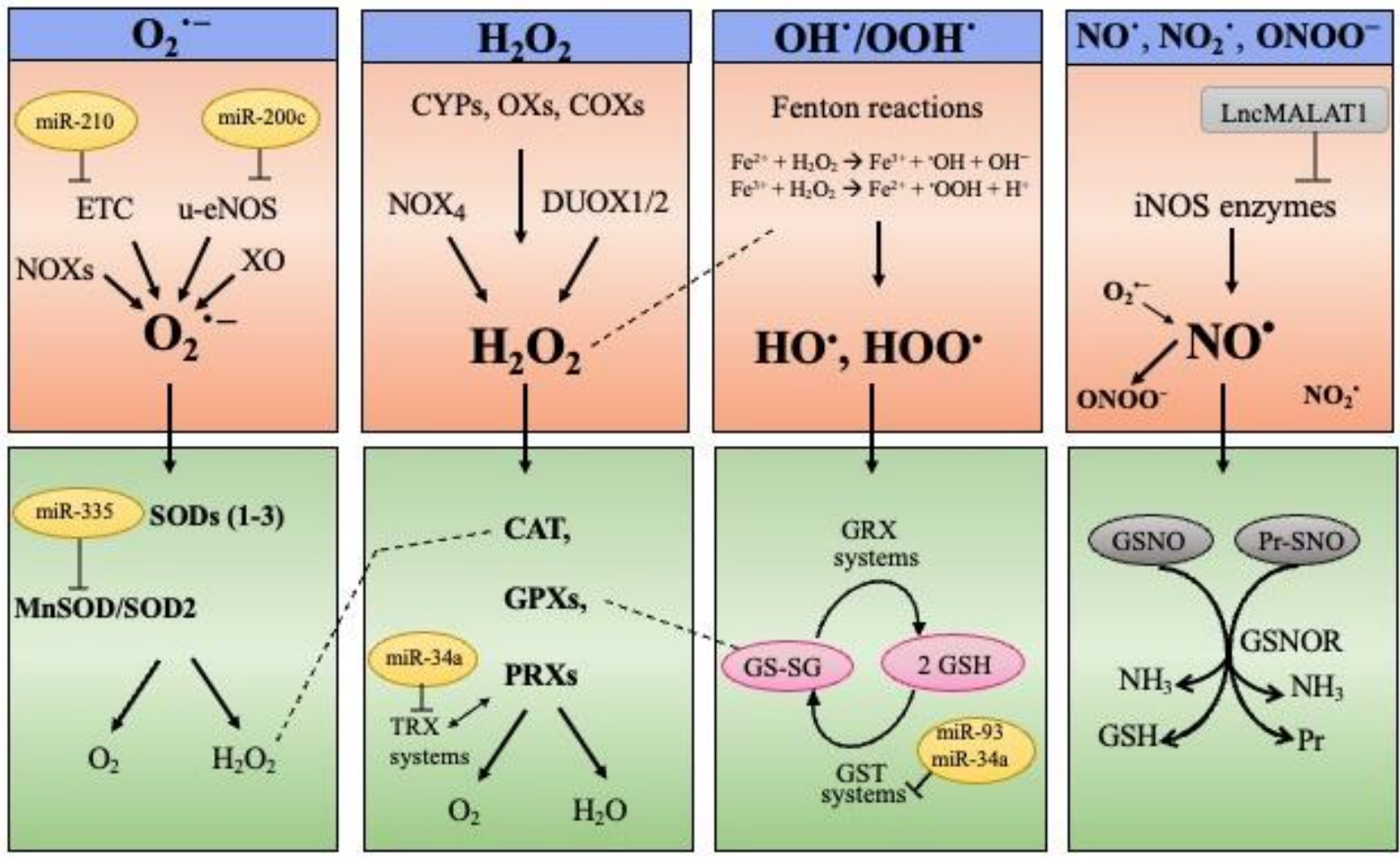

Figure 2. ROS and RNS biological sources and major scavenging pathways. ROS comprise the superoxide anion $\left(\mathrm{O}_{2}^{\bullet-}\right)$, the hydroxyl $\left(\mathrm{HO}^{\bullet}\right)$, and hydroperoxyl $\left(\mathrm{HOO}^{\bullet}\right)$ radicals and the nonradical hydrogen peroxide $\left(\mathrm{H}_{2} \mathrm{O}_{2}\right)$. Prevalent $\mathrm{RNS}$ are the nitric oxide $\left(\mathrm{NO}^{\bullet}\right)$, the radical nitrogen dioxide $\left(\mathrm{NO}_{2}{ }^{\bullet}\right)$, and the peroxynitrite anion $\left(\mathrm{ONOO}^{-}\right) \cdot \mathrm{O}_{2}{ }^{\bullet-}$ can originate inside the mitochondrial electron transport chain (ETC) or from enzymatic reactions catalyzed by $\mathrm{NAD}(\mathrm{P}) \mathrm{H}$ oxidases (NOXs), xanthine oxidase $(X O)$ or uncoupling nitric oxide synthase (u-eNOS). $\mathrm{H}_{2} \mathrm{O}_{2}$ is produced by NOX4, dual oxidase 1 and 2 (DUOX1/2), cytochrome P450s (CYPs), various oxidases (XOs), cyclooxygenases (COXs), as well as transiently by superoxide dismutase (SOD1-3) isoforms. $\mathrm{HO}^{\bullet}$ and $\mathrm{HOO}^{\bullet}$ are directly generated through the Fenton reactions. $\mathrm{NO}^{\bullet}$ is produced by the enzymes nitric oxide synthases (NOSs), while the peroxynitrite anion $\left(\mathrm{ONOO}^{-}\right)$originates from the radical nitrogen dioxide $\left(\mathrm{NO}_{2}{ }^{\bullet}\right)$ combined with $\mathrm{O}_{2}{ }^{\bullet-}$. 
The SOD1-3 are antioxidant isoenzymes involved in the dismutation of $\mathrm{O}_{2}^{\bullet-}$ producing $\mathrm{H}_{2} \mathrm{O}_{2}$, which is then inactivated by the enzymes catalase (CAT), glutathione peroxidases (GPXs), and peroxiredoxins (PRXs). GPXs use glutathione (GSH) to reduce substrates. Oxidized glutathione (GSSG) is reduced back by the glutaredoxin (GRX) system. PRXs instead form intramolecular disulfide bonds, which are then reduced via the thioredoxins (TRXs) system. GSH is also a cofactor of the GSH S-transferase enzymes (GSTs) that eliminate ROS/RNS along with xenobiotics and drugs. The enzyme S-nitrosoglutathione reductase (GSNOR) removes $\mathrm{NO}^{\bullet}$ from S-nitrosoglutathione (GSNO) and nitrosylated proteins (Pr-SNO).

Some microRNAs and long non-coding RNAs (discussed in Section 4) affecting the stress/antioxidant networks are indicated.

Increased ROS/RNS levels can foster a cell switch into senescence [25-27,83,84]. Pioneer studies by Chen et al. first revealed that normal fibroblasts exposed to sub-lethal doses of $\mathrm{H}_{2} \mathrm{O}_{2}$ developed a senescence-like phenotype $[43,44]$. This phenomenon was later expanded to a plethora of conditions and/or external agents interrupting redox homeostasis [51,92-95]. For example, ROS generated by NAD(P)H oxidases, NOX1 and NOX4, are important players in premature senescence induced by oncogenic RAS [87] and constitutive active NOX4 mediates ROS-induced senescence in hematopoietic stem cells (HSCs) [96]. Similarly, increased $\mathrm{NO}^{\bullet}$ levels or its derivatives has been described in pathophysiological processes as senescence/aging [90,91].

Excessive ROS/RNS derived from mitochondria were initially considered as a principal cause of cell senescence [28,92]. Mitochondria are the primary site of ROS/RNS production, but concomitantly they also represent the main targets of oxidative stress, as recently reviewed in [97]. Exposure to ROS/RNS can disrupt ETC integrity, which can in turn, feedback positively to enhance ROS/RNS levels, thereby sustaining senescence through a vicious cycle $[98,99]$. Moreover, healthy cells upon stress can replace damaged mitochondria through selective degradation (mitophagy) and biogenesis. On the contrary, during senescence, mitochondria increase both in number and size due to uncontrolled biogenesis [98-100] and/or to decreased Parkin-mediated mitophagy, involving ROS-mediated trapping of p53 in the cytosol [101]. Therefore, dysfunctional mitochondria contribute to impaired redox homeostasis and senescence.

\subsubsection{Antioxidant Systems and Cell Senescence}

To cope with ROS/RNS toxicity, living cells use sophisticated endogenous antioxidant systems: Enzymatic and non-enzymatic scavengers, able to prevent (or quench) oxidative reactions, and consequently, cell physiology degeneration [21,102]. There is an enzymatic network to intercept and scavenge ROS/RNS (Figure 2). SOD1-3 isoenzymes located in different cell compartments are involved in the dismutation of $\mathrm{O}_{2}{ }^{\bullet-}$ that produces $\mathrm{H}_{2} \mathrm{O}_{2}$ [103]. Zhang et al. observed increased oxidative damages associated with senescence markers in the kidney of SOD1-/- mice [104]. In addition, Kwon et al. reported premature-aging in transgenic mice with altered SOD3 function (R213G variant) [105]. $\mathrm{H}_{2} \mathrm{O}_{2}$ is inactivated by the enzymes catalase, glutathione peroxidases (GPXs), and peroxiredoxins (PRXs) (reviewed in [106]) (Figure 2). Catalase dysfunctions are associated with different oxidative stress-mediated diseases (reviewed in [107]) and cell models from GPX-/- mice featured senescence-like phenotype and increased susceptibility to $\mathrm{H}_{2} \mathrm{O}_{2}$ [108]. Additionally, PRX1-/- mice display reduced lifespan and fibroblasts lacking PRX1 are more susceptible to $\mathrm{H}_{2} \mathrm{O}_{2}$-induced damages [109]. GPXs use the tripeptide glutathione (GSH) to reduce substrates, while PRXs form intramolecular disulfide bonds, which are then reduced via the thioredoxins (TRXs) system [106] (Figure 2).

GSH behaves as a "guardian" of redox status, as well as a mediator of redox signal transduction [110] and some reports point to GSH depletion as the main culprits of oxidative stress favoring senescence $[93,111,112]$. Oxidized glutathione (GSSG) is reduced back to GSH by the glutaredoxin (GRX) system [113] (Figure 2). GRX1 has been recently linked to cell senescence. In fact, GRX1 silencing promotes ROS elevation and activates the 
p53 pathway [114]. GSH is also used by the GSH S-transferase enzymes (GSTs), that in addition to ROS/RNS, eliminate a wide range of toxic molecules, such as xenobiotics and drugs [115]. The antioxidant enzyme S-nitrosoglutathione reductase (GSNOR) removes $\mathrm{NO}^{\bullet}$ from S-nitrosoglutathione (GSNO) and nitrosylated proteins, thereby modulating nitrosative stress signaling (reviewed in [116]) (Figure 2). Of note, GSNOR deficiency is associated with cell senescence and specific features of aging [117].

\subsubsection{NRF2 Antioxidant Pathways}

An endogenous booster of redox homeostasis is the nuclear factor erythroid 2-related factor 2 (NRF2) [118-122]. Under unstressed conditions, newly synthesized NRF2 is degraded since the adaptor protein Keap1 (Kelch-like ECH-associated protein 1) ensures its continuous ubiquitination. Oxidative stress renders Keap1 inactive, thus NRF2 migrates into the nucleus where, mainly in the heterodimer with small musculoaponeurotic fibrosarcoma oncogene homolog (sMAF) proteins, orchestrate a selective transcriptional program aimed at restoring redox balance and counteracting possible deleterious effects due to ROS/RNS increase [120,121]. NRF2 reshapes antioxidant defense systems by inducing the expression of genes sustaining glutathione levels, such as those for GSH biosynthesis, GPXs, TRXs, and PRXs (reviewed in [118-121]). However, the NRF2-responsive genes are not limited to those implicated in thiol-based redox homeostasis since many others can function in detoxification, autophagy, and metabolism, as well as in anti-inflammatory cascades [118-121]. According to its cytoprotective role, NRF2 levels are reduced in senescent cells, as well as in aged tissues [123], thereby establishing persistent ROS/RNS production contributing to induction and maintenance of senescence (reviewed in [118]).

Mounting evidence also links non-coding RNAs with redox homeostasis, and thus with the control of senescence program. These molecules can modulate the redox status by targeting ROS/RNS producing or antioxidant enzymes (Figure 2). This aspect will be further discussed in Section 4.

\subsection{ROS/RNS Signaling Pathways in Senescence (p53, p16, NF- $k B, A M P K$, SIRT, FOXO)}

Loss of prooxidant-antioxidant balance, triggered by increased ROS/RNS production or inefficient antioxidant defense systems primarily due to NRF2 decline, provokes oxidative damages to biomolecules disturbing specific functions, signaling and/or metabolic pathways. This directly or indirectly (through a large set of molecular players) initiates and delivers signaling cascades leading to cell senescence (Figure 3A). In addition, ROS/RNS by inducing irreversible telomeric single-strand DNA breaks could foster the onset of senescence [55].

\subsubsection{Cell Cycle Arrest Pathways}

DNA damage plays a critical role in ROS/RNS-induced premature senescence $[27,43,55]$. In particular, the double-strand DNA breaks initiate a DNA damage response (DDR), which if it becomes persistent converges on two DDR effectors: p53/p21 [7,48-50,62] and/or $\mathrm{pRb} / \mathrm{p} 16[18,49,50]$ (Figure 3A). The oncosoppressor protein p53 arrests cell proliferation by inducing the expression of p21 $1^{\mathrm{Cip} 1}$, a member of the cyclin-dependent kinase (CDK) inhibitor family. The $\mathrm{pRb}$ is a protein that in an hyphosphorylated state blocks proliferation by sequestering E2F/DP complexes necessary for cell cycle progression. The $\mathrm{p} 16^{\mathrm{INK} 4 \mathrm{a}}$ is an inhibitor of other CDKs and, by preventing CDK-mediated phosphorylation of $\mathrm{pRb}$, favors cell cycle arrest. The $\mathrm{p}^{21^{\mathrm{Cip}} 1}$ also contributes to hyphosphorylated $\mathrm{pRb}$ since it can inhibit activities of other CDKs. However, activation of p53 and/or p21 Cip1 tumor suppressor pathways can also occur in a DDR-independent manner [2,3]. DDR activation could also be a subsequent event of replicative stress caused by hyperproliferation stimuli initiated by NOX4-mitogenic ROS axis [124]. 


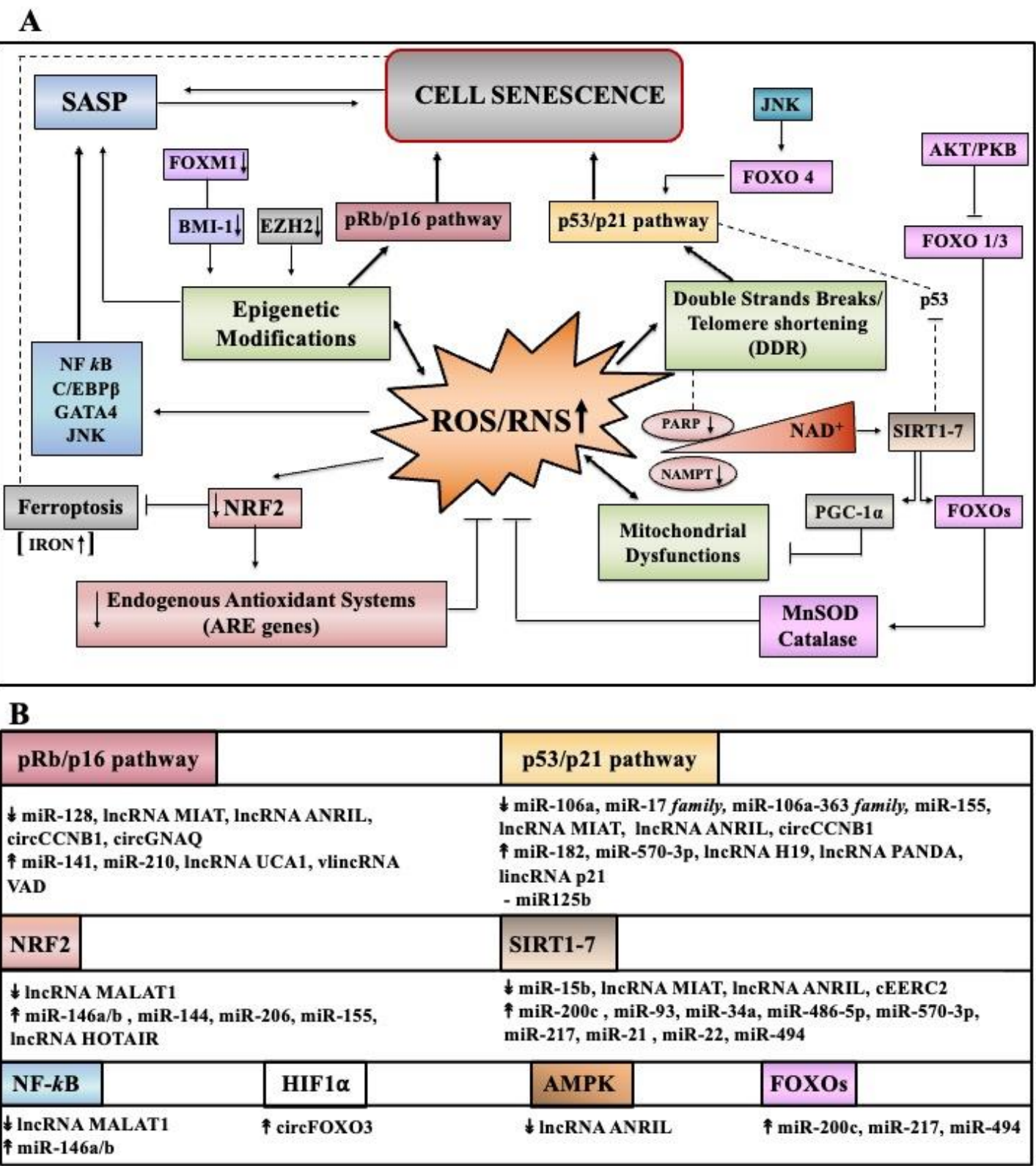

Figure 3. Summary of major pathways initiating senescence through ROS/RNS deregulation. (A) Failure of the antioxidant transcription program arising from NRF2 defects can induce senescence. In fact, NRF2 promotes the induction of numerous cytoprotective genes harboring ARE/s cis-element/s in their promoters. NRF2 also engages protective mechanisms to ferroptosis, thus preventing iron accumulation. Under redox imbalance, numerous molecular effectors/factors can mediate senescenceassociated growth arrest. This relies on the activation of the $\mathrm{p} 53 / \mathrm{p} 21^{\mathrm{CIP} 1}$ and $\mathrm{p} 16^{\mathrm{INK} 4 \mathrm{a}} / \mathrm{Rb}$ pathways Persistent DDR activates the $\mathrm{p} 53 / \mathrm{p} 21^{\mathrm{CIP} 1}$ pathway, while epigenetic changes due to downregulation of BMI-1 and EZH2 proteins of the PCRs complex, induces $\mathrm{p} 16^{\mathrm{INK} 4 \mathrm{a}} / \mathrm{Rb}$ pathway and establishes the SASP profile. SASP induction is mainly regulated by the redox-sensitive NF- $\mathrm{BB}$ pathway, along with $\mathrm{C} / \mathrm{EBP} \beta, \mathrm{GATA} 4$, and JNK transcription factors. Dysfunctional mitochondria can also promote SASP (not shown). Mitochondrial dysfunctions increase ROS/RNS levels that also contribute to telomere damage and epigenetic modifications, and thus sustain senescence. Reduced levels of NAD ${ }^{+}$, a mitochondrial metabolite, affects the activities of sirtuins (SIRT1-7), thus provoking senescence by the $533 / \mathrm{p} 21$ pathway. Alteration of the $\mathrm{NAD}^{+} /$sirtuin pathway also impacts negatively on FOXO and PGC- $1 \alpha$ activities, with consequent ROS elevation and mitochondrial dysfunctions. FOXO transcription factors increase catalase and SOD2 expression. FOXO1/3 are primarily inhibited by AKT and activation of AKT gives rise to senescence through increased intracellular ROS levels. FOXO4 activated 
by JNK induces senescence by engaging the p21 pathway. Low $\mathrm{NAD}^{+}$amounts sustained by dysfunction of PARP1 and NAMPT enzymes also induce senescence. (B) Overview of non-coding RNAs deregulated in senescence that can modulate ROS/RNS signaling pathways. Up and down arrows indicate ncRNA levels that have been found as increased or decreased, respectively in various models of oxidative stress-induced senescence.

\subsubsection{SASP Pathways}

In parallel to cell cycle arrest, the activation of redox-sensitive NF- $\mathrm{KB}$ signaling cascade drives the production of SASP (reviewed in [27,59,65]) (Figure 3A). Schreck et al. first showed that $\mathrm{H}_{2} \mathrm{O}_{2}$ mediates NF- $\mathrm{KB}$ activation [125]. NF- $\mathrm{kB}$ transcription factor is activated by various senescence-inducing pathways [62,126-128], and accordingly, inhibition of canonical NF-KB (RelA/p50) pathway delayed cellular senescence [129]. Among a vast repertoire of NF- $\mathrm{kB}$-dependent genes, the inducible NOS (iNOS) can feed genotoxic peroxynitrite triggering ATM-mediated senescence [90]. There is also evidence recognizing a crosstalk between NF-KB and NRF2 in the senescence program [130]. Other transcription factors, such as CCAAT/enhancer-binding protein- $\beta(\mathrm{C} / \mathrm{EBP} \beta)$ and GATA4, as well as p38 MAP kinase and mammalian target of rapamycin (mTOR) signaling can intervene to produce selective secretome/s [20].

\subsubsection{Metabolic Pathways}

As mentioned in Section 3.1.1, mitochondria homeostasis is essential for cell activities, and disturbances in their integrity/functions can induce senescence $[99,100]$. Mounting evidence suggests that beyond ROS/RNS increase, mitochondria can also trigger senescence through multiple cytosolic effectors/pathways [100]. First, bioenergetic imbalance can stimulate AMP-activated protein kinase (AMPK) that induces permanent arrest via increased p53/p21 in primary fibroblasts [131], and via pRb/p16 in endothelial cells [132]. Among mitochondrial metabolites, $\mathrm{NAD}^{+}$levels when reduced can behave as a signal molecule in senescence and aging (reviewed in [133]) (Figure 3A). In line with this, nicotinamide phosphoribosyltransferase (NAMPT) enzyme involved in the NAD salvage pathway is downregulated during senescence and its re-expression delays senescence in MSCs [134].

Several studies have shown that if $\mathrm{NAD}^{+}$declines, the activities of poly-ADP ribose polymerases (PARPs) and/or of deacetylase sirtuin (SIRT1-7) family are consequently inhibited and this can promote cell senescence (see References in [133]). Reduction of PARP1 activity can lead to activation of DDR signaling, in which PARP1 is a DNA damage sensor [133]. Furthermore, PARP1 regulates SIRT1 functions (directly or indirectly) since in addition to $\mathrm{NAD}^{+}$, they share various substrates (reviewed in [135]).

Beyond deacetylation of histones, SIRT1 deacetylates numerous transcription factors, including p53, PPAR $\gamma$ coactivator 1 alpha (PGC- $1 \alpha$ ), forkhead box O (FOXO), NF-kB, and hypoxia-inducible factor 1 (HIF-1 $\alpha$ ). By deacetylating p53, SIRT1 suppresses its transcriptional activity, and thus the low $\mathrm{NAD}^{+}$can induce senescence sustained by the p53/p21 pathway [136]. SIRT3-5 enzymes are mainly located in the mitochondria and act preserving their homeostasis [137]. Reduced $\mathrm{NAD}^{+}$negatively impacts the SIRT3/PGC$1 \alpha$-dependent pathway [138], affects nucleus-mitochondria communication [139], and deregulates FOXO protective signaling along with mitochondrial unfolded protein response (UPRmt) [140,141] (Figure 3A).

\subsubsection{FOXO Pathways}

FOXO transcription factors are involved in a plethora of biological functions, and thus they can affect senescence [141-144]. NAD $/$ sirtuin pathway post-translationally regulates FOXO activities that at least in many long-lived mutants, are causally involved in lifespan by modulating retrograde ROS signaling [145]. Since FOXOs increase catalase and SOD2 expression and FOXO1/3 factors are primarily inhibited by AKT/PKB (protein kinase B), the activation of AKT gives rise to cell senescence by increasing ROS [146-148]. The AKT role in oxidative stress-induced senescence was also proven in AKT-/- cells that display 
resistance to senescence [147]. On the contrary, FOXO4 fosters senescence via p21 increase, and is stimulated through the c-Jun N-terminal kinase (JNK) signaling [149]. Of note, a very recent article highlights a mitochondrial ROS-JNK signaling pathway to produce cytoplasmic chromatin fragments that trigger SASP [150]. Another member of the FOX family, FOXM1, is involved in the regulation of B cell-specific Moloney murine leukemia virus integration site 1 (BMI-1) expression and can counteract oxidative stress-induced senescence [151] (Figure 3A).

Finally, there is mounting evidence that the deregulated expression of numerous noncoding RNAs, especially microRNAs, can be causally involved in oxidative stress-induced senescence. As summarized in Figure 3B, they can impact the signaling cascades discussed above, via direct or indirect interactions with specific members of redox pathways, which will be covered in Section 4 .

\subsection{ROS/RNS: Links to Epigenetic Changes in Senescence}

ROS/RNS imbalance can produce an alteration in the epigenetic landscape directly or indirectly and ROS/RNS amounts could be regulated by epigenetic mechanisms [24,152]. Epigenetic modifications include DNA methylation, histone modifications, and non-coding RNA activities, which can also work together to sustain the complex program of senescence [31]. One of the recent examples is a regulatory circuit reported by Jung et al., in which increased DNA methyl transferase 3 (DNMT3) activity due to the decrease of specific microRNA, impacts negatively on mitochondrial SOD2 expression, and consequently, induces senescence through ROS elevation [153] (Figure 4A).

\subsubsection{ROS/RNS and DNA Methylation}

ROS and RNS can influence the status of DNA methylation. ROS act directly to modify the methylation status, while the RNS mechanism is less elucidated. The hydroxyl radicals attack cytosines normally methylated at $\mathrm{C} 5(5 \mathrm{mC})$, which become 5hydroxymethylcytosines $(5 \mathrm{hmCs})$. The $5 \mathrm{hmCs}$ can be further oxidized by the ten-eleven translocation methylcytosine dioxygenases (TET) enzymes, and subsequently, this provokes local DNA demethylation [154,155]. ROS can also dampen cytosine methylation by influencing the DNMT enzymatic activities involved in methylation of DNA. It has been reported that $\mathrm{H}_{2} \mathrm{O}_{2}$-induced senescence in normal human cells from different origins is accompanied by decreased expression of DNMT1, thus fostering demethylation of p16 ${ }^{\text {INK4a }}$ promoter region with consequent expression of p16 $[156,157]$. Finally, differential methylation has been reported in senescent cell genome: It seems that hypermethylation of cell-cycle gene promoters, and hypomethylation of constitutive heterochromatin enhances genome instability, thus further promoting permanent arrest (reviewed in $[158,159]$ ).

\subsubsection{ROS/RNS and Histone Modifications}

As previously discussed, ROS/RNS can directly produce DNA damages that are engaged by the kinase ATM/ATR, which is specifically involved in the most frequent histone post-translational modifications, namely the phosphorylation on serine 139 of the histone H2AX variant, a DDR marker [42,57]. ROS/RNS can also increase or decrease other histone modifications, such as acetylation and methylation by affecting enzymatic reactions catalyzed by the histone acetylases/deacetylases (HATs/HDACs) and by histone methylases/demethylases (HMT/HDM), respectively (Figure 3A).

Histone acetylation/deacetylation processes could be shaped by ROS/RNS at various levels, directly or indirectly $[42,155,160]$. For example, ROS/RNS can directly influence epigenetic modifiers, such as the acetylase EP300 and its paralog CREBBP, due to oxidation of key cysteine residues or to the fact that they are mechanistically linked to the deregulation of the class III deacetylases, namely of sirtuins [140,160,161]. As previously mentioned, in addition to histones, SIRTs govern the activities of numerous transcription factors, such as FOXOs, p53, and in turn, the redox regulatory circuits at different levels $[140,160,161]$. 
A

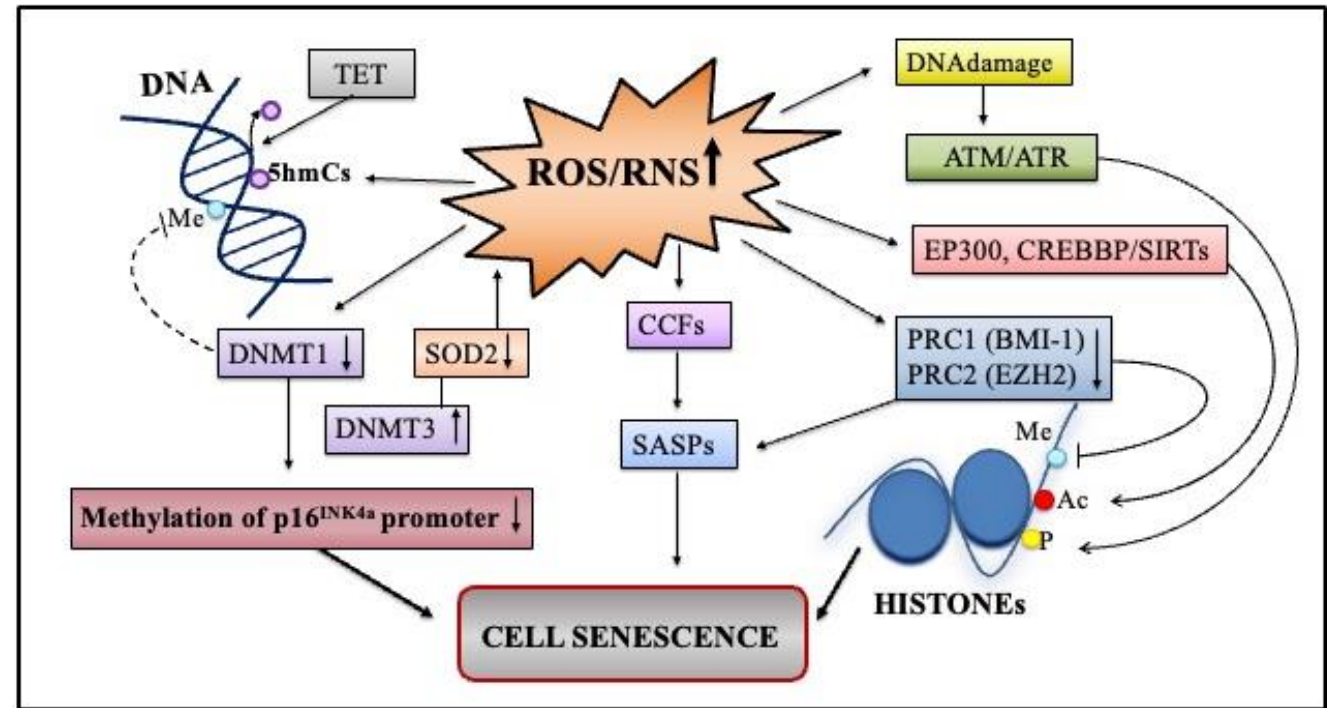

\section{B}

\begin{tabular}{|c|c|c|}
\hline DNMT 1 & PRC1 (BMI-1) & \\
\hline ₹ miR-217, miR-21 & \multicolumn{2}{|c|}{$\begin{array}{l}\ddagger \text { miR-128, IncRNA ANRIL } \\
\uparrow \text { miR-141, IncRNA PANDA }\end{array}$} \\
\hline DNMT 3 & PRC2 (EZH2) & \\
\hline$-\operatorname{miR}-29 a-3 p$, miR-30c-5p & \multicolumn{2}{|c|}{$\begin{array}{l}\text { ٪ IncRNA MALAT } 1, \text { IncRNA ANRIL } \\
\text { miR-210, IncRNA PANDA }\end{array}$} \\
\hline
\end{tabular}

Figure 4. Summary of major epigenetic landscape through ROS/RNS. (A) ROS attack cytosines methylated at C5 (5mC), which become 5-hydroxymethylcytosines (5hmCs). These latter can be further oxidized by TET enzymes prompting local DNA demethylation. Increased activity of DNMT3 reduces SOD2 expression that provokes ROS elevation, and consequently, senescence. On the contrary, ROS/RNS reduce the expression of DNMT1 with consequent demethylation of $\mathrm{p} 16^{\mathrm{INK} 4 \mathrm{a}}$ promoter and increased expression of p16. ROS/RNS can directly generate DNA damages, which are engaged by the kinase ATM/ATR that phosphorylates the serine 139 of the histone H2AX variant. ROS/RNS can reshape histone modifications (such as acetylation and methylation) by altering enzymatic reactions of the histone acetylases/deacetylases, such as EP300 or CREBBP/SIRTs and/or histone methylases/demethylases, such as EZH2, BMI-1 of the PRC complexes. Mitochondrial ROS induce the release of cytoplasmic chromatin fragments involved in SASP stimulation. (B) Overview of non-coding RNAs deregulated in senescence that can impact epigenetic landscape through ROS/RNS signaling pathways. Up and down arrows indicate ncRNA levels that have been found as increased or decreased, respectively in various models of oxidative stress-induced senescence.

Histone methylation/demethylation are dynamic events and coordinate the DNA accessibility for transcription factors. Modifications are principally ensured by two cooperating Polycomb group (PcG) complexes: PRC1 (formed by BMI-1, CBX, HPH, RING1) and PRC2 (composed of EED, SUZ12, EZH2, the methyltransferase) [26,162]. ROS/RNS are implicated in a senescence-driving circuit involving EZH2 downregulation and NOX4 increase through a positive feedback [163]. In line with this, EZH2 and BMI-1, as well as other components of the PcG pathway become downregulated in senescence prompting changes in chromatin landscape, increased $\mathrm{p} 16^{\mathrm{INK} 4 \mathrm{a}}$ expression, and establishment of the SASP [164,165] (Figure 4A). Finally, most types of senescent cells possess peculiar areas of heterochromatin called senescence-associated heterochromatin foci (SAHF), responsible for E2F target genes silencing [49], in parallel with $\mathrm{pRb} / \mathrm{p} 16^{\mathrm{INK} 4 \mathrm{a}}$ activation [166]. SAHF contain heterochromatin markers, such as lysine 9-trimethylated histone H3 (H3K9me3) 
associated with heterochromatic protein 1 (HP1), high-mobility group HMGA proteins, and depletion of Histone H1 [58]. However, SAHF, similar to other epigenetic changes are contest dependent [31].

Mitochondrial ROS are specifically involved in the production of cytoplasmic chromatin fragments in senescent cells harboring $\mathrm{H} 2 \mathrm{AX}$ variant, H3K9me3, and H3K27me3 markers that could stimulate a signaling involved in SASP production [150].

Finally, ncRNAs expression can be influenced by epigenetic modifications, and in particular, lncRNAs can participate in the formation of a specific chromatin-modifying complex to activate or inhibit transcription (Figure 4B).

\section{Non-Coding RNAs in Oxidative Stress-Induced Senescence}

Non-coding RNAs (ncRNAs) comprise a wide range of endogenous transcripts, such as microRNAs (miRNAs), long RNAs (lncRNAs), and circular RNAs (circRNAs), which act as "regulatory" ncRNAs with diverse functions correlated to the regulation of gene expression. Well established regulatory mechanisms of ncRNAs involve transcription, splicing, translation, and stability of mRNAs, as well as genomic control of chromatin status [33,34].

Discoveries over the last decades have highlighted that ncRNAs are highly responsive to different types of stimuli, and thus they are implicated in numerous cellular responses, including oxidative stress-induced senescence [27,35-38].

\subsection{MicroRNAs (miRNAs)}

The most extensively studied regulatory ncRNAs are microRNAs (miRNAs), which are supposed to supervise the expression of about $60 \%$ of human genes, accounting for the possibility that they are essential regulators of most (if not all) physiological processes of organisms, including differentiation, development, aging, as well as metabolic homeostasis [167-171]. Therefore, their dysregulation is widely recognized as a crucial contributor to major human diseases, including cardiovascular, metabolic, and age-related diseases, as well as cancer [171-173].

The miRNAs can directly or indirectly modulate the levels of crucial senescence effectors since they recognize complementary sequences generally localized in the $3^{\prime}$ untranslated regions ( $3^{\prime}$ UTRs) of targeted mRNAs and function with a sequence-specific silencing mechanism [174-176]. The miRNAs exhibit conserved mRNA target sequences across mammalian species, and by down-modulating post-transcriptionally the expression of numerous different genes (up to hundred for a single miRNA), they can influence crucial signaling networks implicated in a variety of stress responses, including those implicated in redox homeostasis [177-179]. Of note, the cellular redox status could also regulate the biogenesis of miRNAs, and thus suggest another complex interplay between ROS/RNS amounts and miRNA production/levels [180].

Numerous miRNAs by targeting molecular effectors of cell senescence and/or crucial players of antioxidant responses lead to oxidative stress and eventually senescence. The selected examples summarize the current knowledge regarding miRNAs in stress-induced senescence (Table 1).

$m i R-106 a$. The first observation that miRNAs can be involved in cell senescence induced by $\mathrm{H}_{2} \mathrm{O}_{2}$ comes from the study by Li et al. [181]. The authors demonstrated that, in primary human cells, oxidative stress-induced senescence was associated with miRNA changes with most as downregulated. Further analyses showed that the downregulation of miR-106a, a member of the miR-17 family, is involved in a p53-independent increase of p21, as miR-106a directly targets the p21 3'UTR transcript. However, the downregulation of miR-106a alone was not able to induce senescence.

$m i R-182$. Li et al. also correlated the upregulation of miR-182 with the decrease of retinoic acid receptor gamma (RARG), an aging-related gene, which was mediated by miR182 putative binding site/s on RARG 3'UTR [181]. Moreover, the miR-182 was recently found as induced in primary epithelial cells from the fallopian tube upon $\mathrm{H}_{2} \mathrm{O}_{2}$ exposure and its ectopic expression triggers cell senescence through the p53/p21 pathway [182]. 
Moreover, the p21 increase was lost in cells harboring p53 mutations, and in this context, miR-182 can rather behave as an "Onco-miR" driving the bypass of senescence and fostering tumorigenesis. This oncogenic role of miR-182 has been demonstrated in other types of cancers $[183,184]$.

miR-17 family and miR-106-363 family. Hackl et al. reported [185] that four miRNAs, namely miR-17, miR-19b, miR-20a, and miR-106a, belonging to the miR-17 family and to the paralogous cluster miR-106a-363, were critically expressed at low levels both in cellular and organismal aging models. Very recently, Tai et al. confirmed the downregulation of miR-106a-5p along with miR-20b-5p (also a member of the miR-106a-363 family) in three human multipotent stromal cell lines treated with $\mathrm{H}_{2} \mathrm{O}_{2}$ [186]. Specific genes of the $\mathrm{p} 21 / \mathrm{CDK} / \mathrm{E} 2 \mathrm{~F}$ pathway, one of the signaling implicated in senescence, were found as directly downregulated by these miRNAs in human multipotent stromal cells under oxidative stress conditions [186].

miR-200 family. $\mathrm{H}_{2} \mathrm{O}_{2}$ exposure of human umbilical vein endothelial cells (HUVEC), a type of cells prone to senescence, leads to induction of the miR-200 family (miR-200a, miR200b, miR-200c, miR-429, and miR-141) and among them ectopic expression of miR-200c promotes senescence by direct downregulation of zinc finger E-box binding homeobox 1 (ZEB1), a transcription factor accumulating in proliferative cells [187]. The same miRNA was also found as upregulated in $\mathrm{H}_{2} \mathrm{O}_{2}$-induced senescence of primary human cells [181]. Furthermore, the paper by Carlomosti et al. [188] demonstrated that upon $\mathrm{H}_{2} \mathrm{O}_{2}$ exposure, induction of miR-200c inversely correlates with SIRT1, FOXO1, and eNOS expression, which were validated as its direct targets. In this paper, the regulatory loop among miR200c and SIRT1/FOXO1/eNOS redox-pathway was demonstrated as a possible contributor to endothelial dysfunctions induced by ROS/RNS deregulation [188] that associate with aging, diabetes, as well as with ischemia and reperfusion processes. It is likely that miR-200 induction is mediated by p53 phosphorylation on Ser33, an $\mathrm{H}_{2} \mathrm{O}_{2}$-induced p53 modification that upregulates the transcription of miR-200 family, at least in liver cell death [189]. Similarly, miR-141, another member of miR-200 family was found as upregulated in replicative and $\mathrm{H}_{2} \mathrm{O}_{2}$-induced senescence [190]. The authors demonstrated that in human diploid fibroblasts, the forced expression of miR-141 blocks proliferation and induces senescence by targeting the $3^{\prime}$ UTR of BMI-1 mRNA [190]. BMI-1 is a member of the PcG gene family that maintains an adult stem cell pool by repressing the $\mathrm{p} 16^{\mathrm{INK} 4 \mathrm{a}}$ locus, and thus preventing premature senescence [191].

$\mathrm{miR} 146 \mathrm{a} / \mathrm{b}$. Other miRNAs upregulated in $\mathrm{H}_{2} \mathrm{O}_{2}$-induced senescence of HCA2 fibroblasts are miR-146a and miR-146b members [192]. It was shown that the activity of NF- $\mathrm{kB}$ was determinant for the induction of miR-146a/b [193] and that miR-146a/b by downregulating IRAK, act as a negative regulator of pro-inflammatory pathways driven by NF- $\mathrm{KB}$ [192] and/or the ETS-related gene (EGR-1/3) and AP-1 transcription factors implicated in SASP production [194]. Moreover, the role of miR-146a increase on the decline of NRF2 during rat liver aging levels has been also reported [195]. Finally, miR$146 \mathrm{a} / \mathrm{b}$ (together with miR-140 and miR-195) have been found as increased in aged bone MSCs [196]. Curiously, the levels of miR-146a were found as decreased in exosomes derived from $\mathrm{H}_{2} \mathrm{O}_{2}$-induced senescent endothelial MSCs, and thus reduction seems to contribute to the alteration of wound healing process [197], but the related pathway/s need to be investigated.

$m i R-206$. The muscle related miR-206 is another miRNA very recently associated with $\mathrm{H}_{2} \mathrm{O}_{2}$-induced senescence in bone marrow-derived MSCs [198]. Oxidative stress-induced senescence in these cells was accompanied by the upregulation of miR-206 targeting alkaline phosphatase $3^{\prime}$ UTR mRNA, and miR-206 inhibition counteracts MSC senescence in vitro. Since oxidative stress-induced senescence is a side effect of stem cell potentiality, the same authors successfully showed that miR-206 down-modulation in MSC transplanted models has beneficial effects on cardiac function [198]. Interestingly, miR-206 was found elevated in aged mouse muscle [199], and since NRF2 downregulates its expression, an association of NRF2 decline with miR-206 increase during aging could be speculated. 
$m i R-144$. Sangokoya et al. reported a functional link between miR-144 and NRF2 levels, since the $3^{\prime}$ UTR of NRF2 mRNA can be directly targeted by the miR-144 [200]. It is well accepted that the deregulation of miR-144/NRF2 regulatory axis disturbs the redox balance and accordingly miR-144 was found as upregulated in aged monkey muscle and its expression can be reversed by caloric restriction [201].

miR-125b. NRF2 transcriptionally activates the miR-125b expression, which is linked to p53 since it directly binds to p53 mRNA and inhibits p53 expression [202], thus reinforcing the concept that a crosstalk between these two transcription factors is necessary in order to set the outcome of stress [203].

miR-34a, -335, -93. Targeting antioxidant effectors mediated by miRNAs may increase ROS/RNS levels, and thus induce premature senescence. This was shown for miR-34a and miR-335, which are increased in aged rat kidney and post-transcriptionally inhibited the expression of mitochondrial SOD2 and TXNRD2 (belonging to the thioredoxins system), respectively. This leads to the increased ROS levels and promotes oxidative stress-induced senescence of young mesangial cells [204]. In aged rat liver, the upregulation of miR-34a together with miR-93 is also implicated in the downmodulation of microsomal glutathione S-transferase 1 (MGST1), an enzyme acting in redox-homeostasis mechanisms [205]. Numerous links between miR-34a increase and cell senescence come from data obtained in different aging systems (aged tissues and cells) [205-208] and in chronic obstructive pulmonary disease (COPD), a lung condition characterized by increased oxidative stress and accelerated senescence [209]. The obtained data showed that SIRT1/6 are direct targets of miR-34a, thus underlying the key role of SIRTs decline in senescence/aging. On the other hand, p53 is involved in the expression of miR-34 family [210]. Therefore, the decrease in SIRT1 via miR-34 a/b/c enhances p53 activity, and thus promotes a cell senescence program [211]. In addition, miR-34a could directly target NAMPT in hepatocytes, thus reducing $\mathrm{NAD}^{+}$biosynthesis, and consequently, SIRT1 activity [212]. Therefore, these factors may act in concert to promote senescence.

miR-486-5p. Kim et al. demonstrated that miR-486-5p induces premature senescence in human adipose-derived stem cells by inhibiting SIRT1, [213], and we also showed that this miRNA was significantly upregulated in stress-induced senescence in primary human fibroblast IMR-90 [214].

miR-570-3p. Baker et al. found that miR-570-3p, highly expressed in COPD patients, which are affected by a form of accelerated aging, directly downregulated SIRT1 expression. By contrast, miR-570-3p inhibition restored SIRT1 levels [215]. They also found that $\mathrm{H}_{2} \mathrm{O}_{2}$ induced expression of $\mathrm{miR}-570-3 \mathrm{p}$ in airway epithelial cells was associated with an increase of p21 levels through the p38MAPK/AP-1 signaling [209].

mir-217. SIRT1 has been found as a direct target of miR-217 in senescence-prone endothelial cells [216]. The authors showed that miR-217 levels are increased in replicative aged cells and that overexpression of miR-217 enhanced FOXO1 acetylation, thus reducing eNOS protein amounts. This could possibly influence the intracellular redox status. Recently, miR-217 has been causally implicated in DNMT1 decrease observed in passageaged human skin fibroblasts [217]. Finally, miR-217 and miR-21 (discussed below) have been both found as increased in extracellular vesicles derived from replicative senescent HUVECs [218].

$m i R-29 a / b / c$. The family of miR-29 (miR-29a/b/c) has been associated with the increase of oxidative stress constitutively found during ageing. In fact, members of miR-29 family were found as elevated in different aged tissues, including the heart [219], muscle, and liver [220], as well as brain [221]. Heid et al. found that the high $\mathrm{H}_{2} \mathrm{O}_{2}$ induces expression of miR-29 family in cardiac cells and this modulation counteracted fibrosis in the zebrafish model carrying the miR-29 family knockout [219], whilst Ugalde et al. reported that normal murine fibroblasts did not increase miR-29a/b/c levels upon transient mild $\mathrm{H}_{2} \mathrm{O}_{2}$ exposure, but their upregulation was rather mediated by persistent DNA-damage involving the p53 pathway [222]. The miR-29 family by downregulating the expression of numerous mRNA, such as collagen genes or epigenetic regulators, alleviates the age-dependent fibrosis 
process [219]. Moreover, a recent work by Ripa et al. associates the increase of miR-29 with age-related iron imbalance demonstrating that miR-29 directly targets iron responsive protein 2 (IRP2), a crucial component of the iron homeostasis [223]. Finally, miR-29 has been linked to premature senescence of hMSCs, where it contributes to epigenetic changes [153]. Early passage hMSCs silenced for DiGeorge critical region 8 (DGCR8), a RNA/hemebinding protein involved in miRNA biogenesis, undergo premature senescence. This was associated with ROS increase, loss of mitochondrial homeostasis, and downregulation of SOD2 transcription. Since in this setting, DNA methyltransferase 3 alpha (DNMT3A) was implicated in senescence-decline, in search for miRNAs targeting $3^{\prime} \mathrm{UTR}$ of DNMT3A, the authors demonstrated that miR-29a-3p along with miR-30c-5p directly repressed DNMT3A expression. Accordingly, ectopic expression of these miRNAs reduced ROS, restored SOD2 protein levels, and improved mitochondrial functions [153].

miR-155. Downregulation of miR-155 has been correlated with oxidative stressinduced senescence [214,224]. The decrease of miR-155 in WI-38 senescent cells causes increased levels of TP53INP1, involved in the p53-mediated growth arrest pathway [224]. The miR-155 is a multifunctional miRNA and can target many transcripts in different cellular contexts, including FOXO3a and HIF- $1 \alpha$, thus contributing to a control of ROS levels. A recent work by Onodera et al. focused on the role of miR-155 during senescence of MSCs [225]. This study demonstrated that miR-155 increased in the bone marrow of aged mice and is involved in ROS generation by suppressing the transcription factor C/EBP $\beta$, which is involved in the regulation of NRF2, SOD1, and HMOX1 expression both in mouse and human MSCs. Since during MSC transplantation, ROS accumulation could limit the efficacy of therapy [226], the same authors demonstrated that MSCs knockout for miR-155 display reduced ROS levels after transplantation [225].

$m i R-494$. The miRNAs can contribute to mitochondrial homeostasis, and in addition to cytosol, a small number also localized in the mitochondria (rewieved in [227]). A well-established role of nuclear miRNAs acting on mitochondrial functions (anterograde signals) is provided by miR-494. By targeting mitochondrial transcription factor A (TFAM) and FOXJ3 mRNAs, miR-494 regulates mitochondrial biogenesis [228]. Other miR-494 targets that can contribute to mitochondrial homeostasis in different cell contexts, include SIRT1, c-Myc [229], DJ/PARK7, a redox-related chaperon [230], and PGC-1 $\alpha$ [231]. In addition, some data indicate a causal role of miR-494 in cell senescence, which is induced by oxidative stress or telomere shortening [214], as well as by DDR-inducing agents [232]. We demonstrated that overexpression of miR-494 in normal IMR-90 fibroblasts induced premature senescence and increased ROS, which can in turn, feedback positively to DDR, thereby sustaining the senescent program [214]. Further analyses revealed that miR-494 directly targets hnRNPA3 and RAD23B 3'UTRs, whose reduced expression was causally related to senescence [233].

miR-128. One of the first miRNAs to be implicated in oxidative stress-induced senescence was miR-128 that directly targets BMI- $13^{\prime}$ UTR in medulloblastoma cells [234]. Bone marrow and thymocyte cells deficient in BMI-1 displayed increased ROS levels along with mitochondrial dysfunctions. These conditions sustain and engage a DDR signal mediated by CHK2/RAD53, independently of $\mathrm{p} 16^{\mathrm{INK} 4 \mathrm{a}}$ pathway activation [235]. Moreover, miR-128 controls the redox-state also through direct regulation of multiple downstream transcripts, including SIRT1 [236], MAFG, a positive interactor of NRF2 [237], and thioredoxin interacting protein (TXNIP) [238].

$m i R-15 b$. Lang et al. recently demonstrated that miR-15b directly targets the mitochondrial deacetylase SIRT4 $3^{\prime}$ UTR. The authors found that SIRT4 increased in stress-induced and replicative senescence, as well as in photoaged human skin in vivo. In addition, miR$15 \mathrm{~b}$ downregulation inversely correlated with SIRT4 protein levels in various senescence models. Accordingly, the enforced inhibition of miR-15b increased SIRT4 expression, which was associated with mitochondrial ROS production that fosters mitochondrial dysfunctions, a hallmark of aged cells [239]. 
miR-210. Mitochondrial functions can be also modulated by miR-210. Specifically, miR-210 increases ROS production via the inhibition of the electron transport chain (ETC) components, such as iron-sulfur cluster scaffold homolog (ISCU) and cytochrome-c oxidase assembly protein (COX10) [240], as well as by targeting some subunits of the complexes I and II [241]. In fact, ectopic expression of miR-210 induced premature cell senescence in human lung IMR-90 fibroblasts [214]. In searching for miRNAs linked to p16-mediated senescence of human normal mammary epithelial cells, Overhoff et al. found that miR-210 directly targets the $3^{\prime}$ UTRs of components of the PcG pathway, namely EED, EZH2, and SUZ12, that consequently mediated the epigenetic increase of p16 [242].

miR-663. Premature senescence induced by $\mathrm{H}_{2} \mathrm{O}_{2}$ in normal WI-38 cells induced miR-663 levels (together with miR-34a and miR-638) [243]. The functions of miR-663 are not well defined in stress-induced senescence. This miRNA is pleiotropic, and its dysregulation correlates with different types of stresses, depending on the genetic contexts and/or the stressor types [244,245]. Recently, miR-663 has been also associated with mitochondria-to-nucleus retrograde communication [246]. Unusually, by direct targeting the $3^{\prime}$ UTR of ubiquinol-cytochrome $C$ reductase complex assembly factor 2 (UQCC2), miR663 stabilizes the UQCC2 transcripts, thus improving the function of ETC complexes in cancer progression [246].

miR-21. Very recently, Mensà et al. reported that miR-21 along with miR-217 is the most enriched miRNA in extracellular vesicles derived from senescent endothelial cells and that both miRNAs directly target DNMT1 [218]. Extracellular vesicles enriched in miR-21 can be transferred to the surrounding young cells, where it can spread signals for an epigenetic program inducing senescence through modulation of DNMT1/SIRT1 levels [218]. A considerable number of studies indicate that mir-21 has a pro-fibrotic and pro-inflammatory role in different models (reviewed in [247]). Since miR-21 could directly target antioxidant genes (i.e., SOD2) or indirectly activate ROS producing enzymes (i.e., NOX4), it can be speculated that the increase in miR-21 functionally contributes to oxidative stress-induced senescence, an important factor in fibrosis. Remarkably, anti-miR21 delivery improves the cardiac function in animal models of heart failure, decreasing cardiac fibrosis and hypertrophy [248]. According to this, miR-21 has been proposed as a candidate biomarker of healthy aging since decreased miR-21 levels have been found in healthy people older than 80 years and centenarians, whereas it was increased during aging and age-related conditions, arguing that lower levels could be beneficial for longevity [249].

miR-22. During in vivo heart aging, cardiac fibroblasts displayed elevated expression of various pro-senescent miRNAs, including miR-22 [250]. In heart fibroblasts, miR-22 selectively targeted the 3'UTR of mimecan/osteglycin mRNA involved in collagen fibrillogenesis, whilst in epithelial cells it downregulated SIRT1/CDK6 levels [250]. Very recently, the miR-22 increase has been associated with mitochondrial ROS induction during ionizing radiations in rat bone marrow mesenchymal stromal cells. The authors found that miR-22 directly targets the $3^{\prime} \mathrm{UTR}$ of the redox-related Redd1/DDIT4 transcript [251].

Table 1. List of microRNAs whose expression and targets/pathways are implicated in oxidative stress-induced senescence. Luciferase assay not reported.

\begin{tabular}{|c|c|c|c|c|}
\hline MicroRNA & Expression Pattern & Target/Pathway & $\begin{array}{l}\text { Cell Models/ } \\
\text { Diseases }\end{array}$ & References \\
\hline miR-106a & down & p21 & HDFs; HDFs (HTMs) & [181] \\
\hline \multirow{2}{*}{ miR-182 } & up & RARG & HDFs; HDFs (HTMs) & [181] \\
\hline & up & p53/p21 pathway & FTEs & [182] \\
\hline \multirow[t]{2}{*}{$\begin{array}{l}\text { miR-17 family and } \\
\text { miR-106a-363 family }\end{array}$} & down & - & $\begin{array}{l}\text { HDFs; HUVECs; RPTECs; T } \\
\text { cells (CD28+); } \\
\text { Isolated BMSCs, FSK-MSCs, T } \\
\text { cells (CD28+) }\end{array}$ & [185] \\
\hline & down & $\begin{array}{c}\mathrm{p} 21 / \mathrm{CDK} / \mathrm{E} 2 \mathrm{~F} \\
\text { pathway }\end{array}$ & WJ-MSCs & [186] \\
\hline
\end{tabular}


Table 1. Cont.

\begin{tabular}{|c|c|c|c|c|}
\hline MicroRNA & Expression Pattern & Target/Pathway & $\begin{array}{l}\text { Cell Models/ } \\
\text { Diseases }\end{array}$ & References \\
\hline \multirow[b]{2}{*}{$\operatorname{miR}-200 c$} & up & ZEB1 & HUVECs, MEFs & [187] \\
\hline & up & - & HDFs, HDFs (HTMs) & [181] \\
\hline \multirow{3}{*}{$\operatorname{miR}-141$} & up & SIRT1, FOXO1, eNOS & HUVECs & [188] \\
\hline & up & $\begin{array}{c}\text { BM1-1/p16 } \\
\text { pathway }\end{array}$ & HDFs (MRC5) & [190] \\
\hline & up & $\begin{array}{l}\text { IRAK1 (?), NF-kB } \\
\text { pathway }\end{array}$ & HDFs (HCA2, BJ, IMR-90) & [192] \\
\hline \multirow{4}{*}{$\mathrm{miR}-146 \mathrm{a} / \mathrm{b}$} & up & $\begin{array}{l}\text { TRAF6/IRAK1/2, } \\
\text { HuR, NF-kb, EGR-1/3, } \\
\text { AP-1 pathway }\end{array}$ & HUVEC & [194] \\
\hline & up & NRF2 & Rat hepatocytes & [195] \\
\hline & up & - & Isolated BMSCs & [196] \\
\hline & $\begin{array}{l}\text { down in } \\
\text { exosomes }\end{array}$ & - & Endothelial MSCs & [197] \\
\hline miR-195 & up & Tert & Isolated BMSCs & [196] \\
\hline \multirow{2}{*}{ miR-206 } & up & Alpl & BMSCs & [198] \\
\hline & - & - & Aged mouse muscle & [199] \\
\hline miR-144 & up & NRF2 & Aged rhesus monkey's muscle & [201] \\
\hline $\operatorname{miR-125b}$ & - & p53 & SH-SY5Y & [202] \\
\hline $\operatorname{miR}-335$ & up & MnSOD & $\begin{array}{l}\text { Aged rat kidney tissues, } \\
\text { mesangial cells }\end{array}$ & [204] \\
\hline \multirow[t]{3}{*}{ miR-93 } & up & MGST1, SIRT1 & Aged rat liver & [205] \\
\hline & up & TXNRD2 & $\begin{array}{l}\text { Aged rat/mouse tissues, } \\
\text { mesangial cells }\end{array}$ & [204] \\
\hline & up & MGST1 & Aged rat liver & [205] \\
\hline \multirow[t]{3}{*}{$\operatorname{miR}-34 a$} & up & - & HUVECs, HAECs, HMVECs & {$[206,208]$} \\
\hline & up & SIRT1/6 & BEAS2Bs; COPD & [209] \\
\hline & up & NAMPT & Isolated hepatocytes & [212] \\
\hline $\operatorname{miR}-486-5 p$ & up & SIRT1 & hAT-MSCs & [213] \\
\hline \multirow[t]{2}{*}{$\operatorname{miR}-570-3 p$} & up & $\begin{array}{l}\text { SIRT1, p21; } \\
\text { p38MAPK/AP-1 } \\
\text { signaling }\end{array}$ & BEASs, SAECs; COPD & [215] \\
\hline & up & $\begin{array}{c}\text { SIRT1; SIRT1/FOXO1 } \\
\text { pathway }\end{array}$ & HUVECs, HAECs, HCAECs & [216] \\
\hline \multirow[t]{3}{*}{$\operatorname{miR}-217$} & up & DNMT1 & Isolated HSFs & [217] \\
\hline & up & - & HUVECS & [218] \\
\hline & up & $\begin{array}{l}\text { Col1a1 col1a2, col15a1 } \\
\text { DNMT3A, DNMT3B }\end{array}$ & $\begin{array}{l}\text { Aged tissues (heart, muscle, } \\
\text { liver, brain), premature aging } \\
\text { model (liver) }\end{array}$ & [219-222] \\
\hline \multirow{2}{*}{$\mathrm{miR}-29 \mathrm{a} / \mathrm{b} / \mathrm{c}$} & up & IRP2 & $\begin{array}{l}\text { Isolated murine neurons, } \\
\text { vertebrate aged models }\end{array}$ & [223] \\
\hline & - & DNMT3A & hAT-MSCs & [153] \\
\hline \multirow[t]{2}{*}{$\operatorname{miR}-30 c-5 p$} & - & DNMT3A & hAT-MSCs & [153] \\
\hline & down & - & HDFs (IMR-90) & [214] \\
\hline \multirow[t]{2}{*}{ miR-155 } & down & $\begin{array}{l}\text { TP53INP1(?); p53 } \\
\text { pathway }\end{array}$ & HDFs (WI-38) & [224] \\
\hline & up & $\mathrm{C} / \mathrm{EBP} \beta$ & $\begin{array}{c}\text { Aged mouse bone marrow } \\
\text { tissues }\end{array}$ & [225] \\
\hline $\operatorname{miR}-494$ & up & hnRPA3, RAD23B & HDFs (IMR-90) & [233] \\
\hline miR-128 & down & $\begin{array}{l}\text { BM1-1/p16 } \\
\text { pathway }\end{array}$ & $\begin{array}{l}\text { Daoy/D283, tissues from } \\
\text { BMI-/- mice }\end{array}$ & [234] \\
\hline
\end{tabular}


Table 1. Cont.

\begin{tabular}{|c|c|c|c|c|}
\hline MicroRNA & Expression Pattern & Target/Pathway & $\begin{array}{l}\text { Cell Models/ } \\
\text { Diseases }\end{array}$ & References \\
\hline $\operatorname{miR}-15 b$ & up & SIRT4 & $\begin{array}{c}\text { HDFs (F623, F357), photoaged } \\
\text { human skin samples }\end{array}$ & [239] \\
\hline \multirow{2}{*}{$\operatorname{miR}-210$} & up & - & HDFs (IMR-90) & [214] \\
\hline & up & EED, EZH2, SUZ12 & HMECs & [242] \\
\hline miR-663 & up & - & HDFs (WI-38) & [243] \\
\hline $\operatorname{miR}-21$ & up & DNMT1/SIRT1 & HUVECs, HAECs, HCAECs & [218] \\
\hline \multirow[t]{2}{*}{ miR-22 } & up & $\begin{array}{l}\text { Mimecan/osteoglycin, } \\
\text { SIRT1, CDK6 }\end{array}$ & $\begin{array}{c}\text { Aged mouse heart, neonatal } \\
\text { HCFs }\end{array}$ & [250] \\
\hline & up & Redd1/DDIT4 & rBMSCs & [251] \\
\hline
\end{tabular}

\subsection{Long RNAs (LncRNAs)}

Long non-coding RNAs (LncRNAs) include multiple RNA species longer than $200 \mathrm{nu}-$ cleotides, which are not translated into proteins. They are now considered crucial regulators in the gene expression acting both in nuclear and cytoplasmic compartments, and at different levels.

They control the architecture and remodeling of chromatin, the transcriptional process by influencing RNA polymerase II activities and stability, translation, as well as posttranslational modifications of transcripts (reviewed in [252]). Therefore, lncRNAs show a plethora and diversity of functions. As a result, studies aimed at understanding their roles are rapidly increasing. The altered expression of several lncRNAs has been associated with oxidative stress-related conditions, including senescence. However, it is important to note that, among the several hundred lncRNAs currently known, only for a few of them the specific functions in oxidative stress response/s have been deeply studied $[27,37,253-257]$ (Table 2).

Abdelmohsen et al. performed a comprehensive evaluation of lncRNAs differentially expressed in senescent human diploid WI-38 fibroblasts by RNA sequencing (RNASeq) [257]. They found a number of antisense transcripts, pseudogene-encoded, and previously annotated lncRNAs, which display an altered expression in senescence (upor downregulated). To our knowledge, this was the first study reporting a collection of senescence-associated lncRNAs.

IncMALAT1. Abdelmohsen et al. demonstrated that the downregulation of MALAT1 is causally involved in senescence [257]. Recently, MALAT1 has been linked to the protective NRF2 signaling in HUVECs during oxidative stress induced by $\mathrm{H}_{2} \mathrm{O}_{2}$. In this context, the forced expression of MALAT1 increases resistance to stress, while its knockdown has the opposite effect. At molecular levels, MALAT1 overexpression reduced KEAP1 protein, thus favoring nuclear NRF2 accumulation [258]. This could be mediated by the methyltransferase EZH2, which affects the histone methylation status inhibiting KEAP1 transcription [259]. Other possible links of MALAT1 with senescence and/or oxidativedegenerative conditions could be mediated by the NF-KB/iNOS pathway [260] and/or p38MAPK signaling cascade [261], but this has not been demonstrated yet in senescence.

IncMIAT. Another lncRNA, found downregulated in human diploid senescent WI38 fibroblasts by Abdelmohsen et al., was MIAT [257]. Recently, Zhao et al. verified that IncMIAT is also reduced and causally involved in $\mathrm{H}_{2} \mathrm{O}_{2}$-induced cell senescence in hepatocellular carcinoma [262]. LncRNAs may act as competitive endogenous RNAs (ceRNAs) to sponge miRNAs, and thus release the transcripts targeted by the specific miRNA/s from translational inhibition and/or degradation [263]. By the intersecting available databases from gain and loss-of-function experiments, the same authors indeed found that MIAT acts as a ceRNA for miR-22-3p, which directly targets SIRT1 3'UTR. Therefore, knockdown of MIAT, by releasing miR-22-3p, decreased SIRT1 levels and promoted senescence through $\mathrm{p} 53 / \mathrm{p} 21$ and $\mathrm{p} 16 / \mathrm{pRb}$ pathways [262]. 
IncH19. In another model of $\mathrm{H}_{2} \mathrm{O}_{2}$-induced senescence using central nucleus pulposus cells (NPCs), miR-22 was also found to be sponged by lncH19, a multifaceted lncRNA which is increased in various degenerative conditions [264]. The authors demonstrated that $\mathrm{H} 19$ is causally implicated in the effects of $\mathrm{H}_{2} \mathrm{O}_{2}$ and that the increased $\mathrm{H} 19$ by sequestering miR-22, a direct inhibitor of the lymphoid enhancing factor-1 (LEF1), could activate the downstream Wnt/ $\beta$-catenin signaling contributing to degenerative events [264]. Similarly, the high $\mathrm{H} 19$ has been recently implicated in cardiomyocyte senescence functioning as a ceRNA for miR-19a [265]. In this work, Zhuang et al. demonstrate that the increase of H19, by scavenging miR-19a, consequently upregulated the suppressor of cytokine signaling 1 (SOCS1) expression (a target of this miRNA), thus enhancing the p53/p21 pathway [265]. Recently, H19 was found as downregulated in vascular endothelial senescence and its decline in vivo reduces angiogenesis and favors a pro-inflammatory environment associated with IL-6 signaling and STAT3 pathway activation [266]. Finally, other studies exploiting a miRNA crosslinking and immunoprecipitation (miR-CLIP) appoach, previously identified that miRNA partners of H19 comprise members of the miR-17r-5p family [267]. However, the implication of $\operatorname{lncH} 19 / \mathrm{miR}-17-5 \mathrm{p}$ axis in stress-induced senescence has not been fully elucidated yet.

IncANRIL. The decrease of the antisense noncoding RNA of the INK4 locus, ANRIL, has been often associated with senescence. In fact, ANRIL can directly recruit the polycomb repressive complexes PRC1 and PRC2 to repress the neighbor INK4b-ARF-INK4a locus encoding p15INK4b, p14ARF, and p16 ${ }^{\mathrm{INK} 4 \mathrm{a}}$, respectively. In this case, ANRIL inhibits senescence sustaining proliferation (reviewed in [268]). Very recently, Tan et al. reported that ANRIL antagonized the senescence of vascular smooth muscle cells by sponging miR-181a, which directly targets $3^{\prime}$ UTR SIRT1 mRNA, thus reducing the cell cycle arrest mediated by the p53/p21 pathway [269]. Moreover, Du et al. demonstrated that ANRIL overexpression alleviated $\mathrm{H}_{2} \mathrm{O}_{2}$-induced cell injury in human lens epithelial cells by mediating miR-21 upregulation that activates the antioxidant AMPK/ $\beta$-catenin pathway. Importantly, ANRIL and miR-21 exhibited a decreased expression in cataract patient tissues [270].

IncHOTAIR. The lncHOTAIR is directly upregulated by NF- $\mathrm{kB}$ in response to DNA damage, and its possible contribution to the positive-feedback loop cascade during DDRinduced signal senescence has been reported in ovarian cancer [271]. Yoon et al. first demonstrated that levels of HOTAIR increase during senescence, and that in this case, it acts as a platform to recruit selected proteins for the ubiquitin-proteasome pathway [272]. Recently, HOTAIR has been implicated in oxidative stress-induced damages in cardiomyocytes [273]. In H9c2 cells, HOTAIR targets miR-125, and knockdown of HOTAIR significantly increased miR-125 levels in both normal and oxidative stress conditions. As matrix metalloproteinases-2 (MMP2) is a direct target of miR-125, the HOTAIR/miR-125/MMP2 signaling pathway has been proposed to regulate the oxidative stress response upon myocardium injury [273]. In addition, HOTAIR is increased in degenerative conditions of human NPCs driving premature senescence, apoptosis, and ECM degradation [274].

IncPANDA. Levels of lncRNA PANDA are regulated by p53 and were increased in replicative and oncogenic RAS-induced senescent cells [275]. At molecular levels, in proliferating cells, PANDA interacts with hnRNPU (also called scaffold-attachment-factor A (SAFA)), a scaffold protein that binds ncRNAs and PRC1/2 components, thus recruiting a repressive complex on the genes that activate senescence, such as p21. During senescence, since SAFA is decreased, PANDA sequesters the NF-YA transcription factor, thus impeding the expression of NF-YA-dependent proliferative genes. According to this, PANDA depletion in BJ fibroblasts promotes senescence entry [275]. However, the PANDA implication in stress-induced senescence has not been investigated yet.

lincRNA-p21. Recently, Xia et al. reported that long intergenic (linc) RNA-p21 was upregulated in bone marrow MSCs isolated from aged mice, and this is associated with increased intracellular ROS production and reduced Wnt/ $\beta$-catenin pathway [276], a signal cascade declining during stem cell ageing [277]. The authors found that knockdown of lincRNA-p21 increased proliferation of aged MSCs, decreased ROS generation, and these 
effects were abolished by silencing $\beta$-catenin, thereby linking lincRNA-p21, oxidative stress, and Wnt/ $\beta$-catenin pathway [276]. LincRNA-p21 is a transcriptional target of p53 and cooperates with hnRNPK to the p53-mediated activation of p21 transcription, albeit this activity was unrelated to the senescence program [278].

IncUCA1. Kumar et al. showed that during senescence IncRNA UCA1 sequesters hnRNPA1, a RNA-binding protein destabilizing p $16^{\mathrm{INK} 4 \mathrm{a}}$ transcripts, thus contributing to improve $\mathrm{p} 16^{\mathrm{INK} 4 \mathrm{a}}$ protein levels [279]. In fact, UCA1 transcript levels were increased in premature senescence induced by oncogenic RAS and accordingly its forced expression rapidly induced senescence. The same authors also reported that in young cells, UCA1 transcription is directly inhibited by a repressor complex composed of a coactivator of AP1 and estrogen receptor/T-box transcription factor3 (CAPER $\alpha / \mathrm{TBX} 3$ ), also involved in $\mathrm{p} 16^{\mathrm{INK} 4 \mathrm{a}}$ and $\mathrm{Rb}$ silencing [279].

vlincRNA VAD. The very long intergenic non-coding (vlinc) RNA antisense to DDAH1 (VAD) also modulates the chromatin structure of the p16 $6^{\mathrm{INK} 4 \mathrm{a}}$ locus. Lazorthes et al. first demonstrated that the transcription of VAD was strongly induced during oncogenic RAF-induced senescence and that ectopic silencing of VAD in senescent cells reversed some features of senescent phenotype [280]. At molecular levels, VAD contributes to the transcriptional activation of INK4a locus by blocking the incorporation of the repressive histone variant H2A.Z at the promoter of INK4a gene [280]. Since DDAH1 is related to the NO signaling [281], an important pathway in cardiovascular physiology, a functional link between VAD and oxidative stress-related senescence could be speculated, albeit not investigated in that paper.

Table 2. List of lncRNAs whose expression and targets/pathways are implicated in oxidative stressinduced senescence.

\begin{tabular}{|c|c|c|c|c|}
\hline LncRNA & Expression Pattern & Target/Pathway & $\begin{array}{l}\text { Cell Models/ } \\
\text { Diseases }\end{array}$ & Reference \\
\hline \multirow{5}{*}{ MALAT1 } & down & - & HDFs (WI-38) & [257] \\
\hline & down & $\begin{array}{l}\text { Keap1/NRF2 } \\
\text { pathway }\end{array}$ & HUVECs & [258] \\
\hline & down & EZH2 & MMs & [259] \\
\hline & down & $\begin{array}{c}\text { NF-kB/iNOS } \\
\text { pathway }\end{array}$ & Endometrial tissues & [260] \\
\hline & down & p38/MAPK signaling & HLECs & [261] \\
\hline MIAT & $\begin{array}{l}\text { down } \\
\text { down }\end{array}$ & miR-22-3p & $\begin{array}{c}\text { HDFs (WI-38) } \\
\text { Hepatocellular carcinoma } \\
\text { tissues, HCC }\end{array}$ & $\begin{array}{l}{[257]} \\
{[262]}\end{array}$ \\
\hline H19 & $\begin{array}{l}\text { up } \\
\text { up } \\
\text { down }\end{array}$ & $\begin{array}{c}\text { miR-22/Wnt } / \beta \text { catenin } \\
\text { miR-19a } \\
\text { IL-6 signaling/ STAT3 } \\
\text { pathway }\end{array}$ & $\begin{array}{c}\text { NCPs } \\
\text { Isolated NMVCs } \\
\text { Aged mice tissues, } \\
\text { HUVECs }\end{array}$ & $\begin{array}{l}{[264]} \\
{[265]} \\
{[266]}\end{array}$ \\
\hline ANRIL & $\begin{array}{l}\text { down } \\
\text { down }\end{array}$ & $\begin{array}{c}\text { miR-181/SIRT1 } \\
\text { miR-21 }\end{array}$ & $\begin{array}{c}\text { VSMCs } \\
\text { Patient tissues, HLECs }\end{array}$ & $\begin{array}{l}{[269]} \\
{[270]}\end{array}$ \\
\hline HOTAIR & $\begin{array}{l}\text { up } \\
\text { up }\end{array}$ & $\begin{array}{c}- \\
\text { Protein ubiquitination } \\
\text { miR-125 }\end{array}$ & $\begin{array}{c}\text { Epithelial ovarian cancer } \\
\text { cells, ovarian tissues } \\
\text { HeLa, HDFs (IDH4, WI-38) } \\
\text { H9c2S }\end{array}$ & $\begin{array}{l}{[271]} \\
{[272]} \\
{[273]}\end{array}$ \\
\hline PANDA & up & $\begin{array}{l}\text { SAFA/hnRNPU; } \\
\text { NF-YA }\end{array}$ & HDFs (BJ, WI-38) & [275] \\
\hline LincRNA-p21 & up & Wnt $/ \beta$ catenin & Isolated BMSCs & [276] \\
\hline UCA1 & up & hnRNPA1 & HDFs (HFFs), MEFs & [279] \\
\hline VAD & up & INK4 locus & $\begin{array}{l}\text { HDFs (WI38- hTERT } \\
\text { RAF1-ER, IMR90) }\end{array}$ & [280] \\
\hline
\end{tabular}




\subsection{Circular RNAs (circRNAs)}

The role of circRNAs in oxidative stress-induced senescence is underexplored. The circRNAs are a type of endogenous non-coding RNA molecules that are covalently close and mainly produced by a non-canonical splicing event called "back-splicing" (reviewed in [282-284]). The roles of circRNAs in different physiological and pathological processes, including cardiovascular diseases and neurological disorders, as well as cancer have been reported $[283,284]$. Most of these circRNAs act by sequestering miRNAs (miRNA sponges/decoys), while others can interact with RNA-binding proteins to suppress or enhance their activities. In addition, they can function as scaffolds for complex assembly and localization [284] (Table 3).

circPVT1. A group of circRNAs deregulated (up- or downregulated) in replicative senescence of WI-38 cells were recently identified by Panda et al. [285]. Among the downregulated circRNAs, circPVT1 was causally related to senescence since its silencing favors the induction of senescence specific markers, including the increased level of p53 protein. The authors through pull-down experiments also demonstrated that circPVT1 acts as a sponge for let-7, a miRNA involved in senescence [243]. Therefore, cirPVT1, by inhibiting let-7 activity, elevated cell proliferation and this was mediated by IGF2BP1, KRAS, and HMGA2 protein increases, whose transcripts are direct targets of let-7 [285].

circFOXO3. Levels of circFOXO3 are induced in aged murine tissues (hearts, lung, derma, and intestine), as well as in different cell lines upon $\mathrm{H}_{2} \mathrm{O}_{2}$ treatments. The circFOXO3 has been implicated in cardiac senescence since its silencing reduces senescence markers in vitro and attenuated doxorubicin-induced cardiomyopathy in mice. In search for possible interactors of circFOXO3, the authors examined its effects on ID, HIF1 $\alpha, \mathrm{E} 2 \mathrm{~F} 1$, and FAK protein localization and demonstrated that circFOXO3 interacted and trapped these factors in the cytoplasm upon $\mathrm{H}_{2} \mathrm{O}_{2}$ treatments, thus inhibiting their functions [286]. circCCNB1. Yu et al. found circCCNB1 strongly under-expressed in premature senescence induced by irradiation of 2BS fibroblasts [287]. Ectopic reduction of circCCNB1 in 2BS cells induced the expression of p53, p21, and p16 proteins. The authors also demonstrated that circCCNB1 directly sponges miR-449a, thus preventing its binding to the $3^{\prime} \mathrm{UTR}$ of CCNE2 (Cyclin E2) mRNA, and thus inhibiting the senescence process [287].

circGNAQ. Very recently, Wu et al. correlated circGNAQ to the senescence of endothelial cells [288]. The levels of circGNAQ were reduced in senescent endothelial cells, as well as in aorta tissues from aged mice and in human blood samples from old people. The authors reported that silencing of circGNAQ accelerated senescence and induced p16 protein levels accompanied by reduced angiogenesis, while the overexpression has opposite effects. Moreover, by in vivo precipitation of circRNAs, the authors identified a number of candidate miRNAs. Among these miRNAs, they found the binding with miR-146a-5p, which was particularly increased. Further analyses demonstrated that circGNAQ sponges miR-146a-5p, which functionally affects the expression of polo-like kinase2 (PLK2), an enzyme implicated in cell cycle progression. Of interest, mice injected with circGNAQ showed reduced signs of atherosclerosis after the high fat diet [288].

circERCC2. Xie et al. extracted nine downregulated circRNAs from human publicly expression datasets of intervertebral disc disease (IVDD) and confirmed that circERCC2 was the most decreased in IVDD samples [289]. Similarly, bioinformatic analyses on miRNA datasets (further confirmed in IVDD samples) bring out miR-182-5p as a putative target of circERCC2. Moreover, the ectopic expression of circERCC2 in NPCs inhibited deleterious effects of the oxidative stress inducing agent tert-Butyl hydroperoxide on mitochondria (TBHP). Similar results were obtained upon miR-182-5p silencing. These effects are mediated by SIRT1, a downstream target of miR-182-5p [289]. 
Table 3. List of circRNAs whose expression and targets/pathways are implicated in oxidative stress-induced senescence.

\begin{tabular}{|c|c|c|c|c|}
\hline circRNA & Expression Pattern & Target/Pathway & $\begin{array}{l}\text { Cell Models/ } \\
\text { Diseases }\end{array}$ & Reference \\
\hline circPVT1 & down & $\begin{array}{c}\text { Let-7/IGF2BP1, KRAS, } \\
\text { HMGA2 }\end{array}$ & HDFs (WI-38) & [285] \\
\hline circFOXO3 & up & ID1, E2F1, HIF1 $\alpha$, FAK & $\begin{array}{l}\text { Aged human and murine } \\
\text { heart tissues, Isolated } \\
\text { cardiomyocytes, MEFs, } \\
\text { MCFs, NIH3T3, B16 }\end{array}$ & [286] \\
\hline $\operatorname{circCCNB1}$ & down & miR-449a/CCNE2 & HDFs (2BSs, IMR-90) & [287] \\
\hline circGNAQ & down & miR-146a-5p/PLK2 & $\begin{array}{c}\text { Aged aorta tissues, blood } \\
\text { from old peoples HUVECs, } \\
\text { HCAECs }\end{array}$ & [288] \\
\hline circERCC2 & down & miR-182-5p/SIRT1 & NPCs, IVDD & [289] \\
\hline
\end{tabular}

\section{Conclusions}

Even though cell senescence is a physiological program to arrest proliferation of damaged/harmful cells, this process is now considered an important contributor in aging and age-related pathologies. Chronic increase of oxidative stress is a driving factor in the development of cell senescence and consequent age-related functional decline. Accumulation of senescent cells impacts on the functionality of organs/tissues and senescence of adult stem cell pools also hinders tissue renewal in vivo. Therefore, drugs/treatments or interventions that can specifically contribute to fine-tune the redox cellular status are considered possible strategies to treat or even prevent the accumulation of senescent cells, and thus age-related diseases. Senotherapeutic and senomorphic drugs that specifically target senescent cells are considered promising strategies, but limited by the lack of studies on long-term effects in humans.

Epigenetic changes that were previously considered imprinted for a specific gene expression profile, nowadays are indeed considered a dynamic event as transcription itself. Epigenetic therapies based on ncRNAs are promising, but still very much in infancy. However, mild perspectives on clinical usages of miRNAs are now emerging as candidate diagnostic circulating biomarkers. Future studies on specific in vivo functions of lncRNAs are needed to shed light on their impacts on oxidative stress-induced senescence since researchers have only recently started to ascribe precise functions for lncRNAs. Moreover, studies on circRNAs as new players in redox regulatory networks, as well as in cell senescence are a very open field. Systematic assessment by gain and loss-of-function and/or by circRNA-miRNA-RBP/s (RNA binding protein/s) interaction studies will be important to better define circRNA role/s in senescence context, and to achieve the results appropriate to address research for therapeutic goals.

Author Contributions: Conceptualization and design, D.L.-B., K.A. and R.F.; writing-original draft preparation, C.P., G.M. and R.F.; writing-review and editing, D.L.-B., K.A. and R.F. All authors have read and agreed to the published version of the manuscript.

Funding: This work was supported by Ministero dell' Istruzione, dell' Università e della Ricerca (MIUR) to Consorzio Interuniversitario di Biotecnologie (DM 738, 08.08.2019; CIB N.36/20 to R.F.)

Conflicts of Interest: The authors declare no conflict of interest.

$\begin{array}{ll}\text { Abbreviations } & \\ \text { 2BS } & \text { human fetal lung diploid fibroblasts } \\ \text { AKT/PKB } & \text { serine/threonine-protein kinase 1/protein kinase B } \\ \text { BEAS-2B } & \text { human non-tumorigenic lung epithelial cells } \\ \text { BJ } & \text { B cell-specific Moloney murine leukemia virus integration site 1 } \\ \text { BMI-1 } & \end{array}$




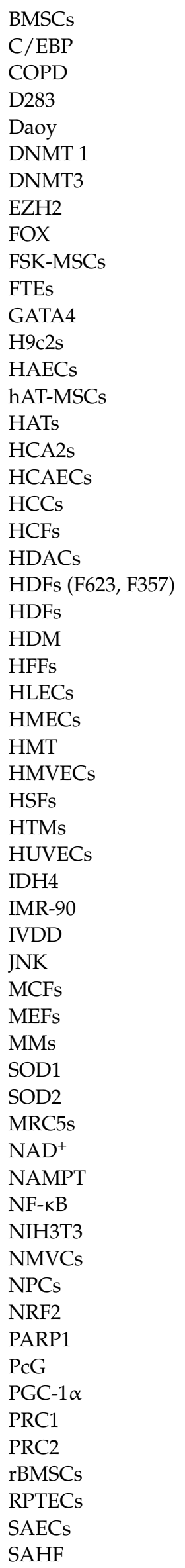

bone marrow mesenchymal stem cells CCAAT/enhancer-binding protein beta chronic obstructive pulmonary disease medulloblastoma cell line medulloblastoma cell line DNA methyl transferase 1 DNA methyl transferase 3 enhancer of zeste 2 polycomb repressive complex 2 subunit Forkhead box human foreskin-mesenchymal stem cells fallopian tube epithelial cells GATA binding protein 4 rat cardiomyoblast cells human aortic endothelial cells human adipose tissue-derived mesenchymal stem cells histone acetylases human foreskin fibroblasts human coronary artery endothelial cells hepatocellular carcinoma cell lines human cardiac fibroblasts histone deacetylases primary human dermal fibroblasts human diploid fibroblasts histone demethylases human foreskin fibroblasts human lens epithelial cells human normal mammary epithelial cells histone methylases microvascular endothelial cells human skin fibroblasts human trabecular meshwork cells human umbilical vein endothelial cells 1MR90-D305.2H4 cell line human fetal lung fibroblasts intervertebral disc disease c-Jun N-terminal kinase mouse cardiac fibroblasts mouse embryonic fibroblasts multiple myeloma cell lines copper and zinc superoxide dismutase manganese superoxide dismutase human fetal lung fibroblasts nicotinamide adenine dinucleotide nicotinamide phosphoribosyltransferase nuclear factor kappa-light-chain-enhancer of activated B cells embryonic fibroblast cell line neonatal mouse ventricular cells nucleus pulpous cells nuclear factor erythroid 2-related factor 2 poly-ADP ribose polymerase 1 polycomb group PPAR $\gamma$ coactivator 1 alpha polycomb repressive complex 1 polycomb repressive complex 2 rat bone marrow mesenchymal stromal cells primary renal proximal tubule epithelial cells human primary small airway epithelial cells senescence-associated heterochromatin foci 


$\begin{array}{ll}\text { SASP } & \text { senescence-associated secretory phenotype } \\ \text { SH-SY5Y } & \text { human neuroblastoma cell line } \\ \text { SIRTs } & \text { sirtuins } \\ \text { TET } & \text { ten-eleven translocation methylcytosine dioxygenases } \\ \text { VSMCs } & \text { vascular smooth muscle cells } \\ \text { WI-38 } & \text { human fetal lung fibroblasts } \\ \text { WI38- hTERT RAF1-ER } & \text { immortalized human fetal lung fibroblast cells } \\ \text { WJ-MSCs } & \text { Wharton's jelly-derived mesenchymal stromal cells }\end{array}$

\section{References}

1. Burton, D.G.; Krizhanovsky, V. Physiological and pathological consequences of cellular senescence. Cell. Mol. Life Sci. 2014, 71, 4373-4386. [CrossRef]

2. Munoz-Espin, D.; Canamero, M.; Maraver, A.; Gomez-Lopez, G.; Contreras, J.; Murillo-Cuesta, S.; Rodriguez-Baeza, A.; VarelaNieto, I.; Ruberte, J.; Collado, M.; et al. Programmed cell senescence during mammalian embryonic development. Cell 2013, 155, 1104-1118. [CrossRef] [PubMed]

3. Storer, M.; Mas, A.; Robert-Moreno, A.; Pecoraro, M.; Ortells, M.C.; di Giacomo, V.; Yosef, R.; Pilpel, N.; Krizhanovsky, V.; Sharpe, J.; et al. Senescence is a developmental mechanism that contributes to embryonic growth and patterning. Cell 2013, 155, 1119-1130. [CrossRef] [PubMed]

4. Yun, M.H.; Davaapil, H.; Brockes, J.P. Recurrent turnover of senescent cells during regeneration of a complex structure. eLife 2015, 4, e05505. [CrossRef]

5. Collado, M.; Gil, J.; Efeyan, A.; Guerra, C.; Schuhmacher, A.J.; Barradas, M.; Benguria, A.; Zaballos, A.; Flores, J.M.; Barbacid, M.; et al. Tumour biology: Senescence in premalignant tumours. Nature 2005, 436, 642. [CrossRef]

6. Michaloglou, C.; Vredeveld, L.C.; Soengas, M.S.; Denoyelle, C.; Kuilman, T.; van der Horst, C.M.; Majoor, D.M.; Shay, J.W.; Mooi, W.J.; Peeper, D.S. BRAFE600-associated senescence-like cell cycle arrest of human naevi. Nature 2005, 436, 720-724. [CrossRef] [PubMed]

7. Chen, Z.; Trotman, L.C.; Shaffer, D.; Lin, H.K.; Dotan, Z.A.; Niki, M.; Koutcher, J.A.; Scher, H.I.; Ludwig, T.; Gerald, W.; et al. Crucial role of p53-dependent cellular senescence in suppression of Pten-deficient tumorigenesis. Nature 2005, 436, 725-730. [CrossRef]

8. $\quad$ Braig, M.; Lee, S.; Loddenkemper, C.; Rudolph, C.; Peters, A.H.; Schlegelberger, B.; Stein, H.; Dorken, B.; Jenuwein, T.; Schmitt A.C. Oncogene-induced senescence as an initial barrier in lymphoma development. Nature 2005, 436, 660-665. [CrossRef] [PubMed]

9. Xue, W.; Zender, L.; Miething, C.; Dickins, R.A.; Hernando, E.; Krizhanovsky, V.; Cordon-Cardo, C.; Lowe, S.W. Senescence and tumour clearance is triggered by p53 restoration in murine liver carcinomas. Nature 2007, 445, 656-660. [CrossRef] [PubMed]

10. Jeyapalan, J.C.; Ferreira, M.; Sedivy, J.M.; Herbig, U. Accumulation of senescent cells in mitotic tissue of aging primates. Mech. Ageing Dev. 2007, 128, 36-44. [CrossRef]

11. Van Deursen, J.M. The role of senescent cells in ageing. Nature 2014, 509, 439-446. [CrossRef]

12. Martinez-Cue, C.; Rueda, N. Cellular Senescence in Neurodegenerative Diseases. Front. Cell. Neurosci. 2020, 14, 16. [CrossRef] [PubMed]

13. Fyhrquist, F.; Saijonmaa, O.; Strandberg, T. The roles of senescence and telomere shortening in cardiovascular disease. Nat. Rev. Cardiol. 2013, 10, 274-283. [CrossRef] [PubMed]

14. Schafer, M.J.; Miller, J.D.; LeBrasseur, N.K. Cellular senescence: Implications for metabolic disease. Mol. Cell. Endocrinol. 2017, 455, 93-102. [CrossRef] [PubMed]

15. Fumagalli, M.; d'Adda di Fagagna, F. SASPense and DDRama in cancer and ageing. Nat. Cell Biol. 2009, 11, 921-923. [CrossRef] [PubMed]

16. Davalos, A.R.; Coppe, J.P.; Campisi, J.; Desprez, P.Y. Senescent cells as a source of inflammatory factors for tumor progression Cancer Metastasis Rev. 2010, 29, 273-283. [CrossRef] [PubMed]

17. Takasugi, M.; Okada, R.; Takahashi, A.; Chen, D.V.; Watanabe, S.; Hara, E. Small extracellular vesicles secreted from senescent cells promote cancer cell proliferation through EphA2. Nat. Commun. 2017, 8, 15729. [CrossRef] [PubMed]

18. Baker, D.J.; Wijshake, T.; Tchkonia, T.; LeBrasseur, N.K.; Childs, B.G.; van de Sluis, B.; Kirkland, J.L.; van Deursen, J.M. Clearance of p16Ink4a-positive senescent cells delays ageing-associated disorders. Nature 2011, 479, 232-236. [CrossRef] [PubMed]

19. Vina, J. The free radical theory of frailty: Mechanisms and opportunities for interventions to promote successful aging. Free Radic. Biol. Med. 2019, 134, 690-694. [CrossRef]

20. Birch, J.; Gil, J. Senescence and the SASP: Many therapeutic avenues. Genes Dev. 2020, 34, 1565-1576. [CrossRef] [PubMed]

21. Sies, H.; Jones, D.P. Reactive oxygen species (ROS) as pleiotropic physiological signalling agents. Nat. Rev. Mol. Cell Biol. 2020, 21, 363-383. [CrossRef] [PubMed]

22. Furuta, S. Basal S-Nitrosylation Is the Guardian of Tissue Homeostasis. Trends Cancer 2017, 3, 744-748. [CrossRef] [PubMed]

23. Di Meo, S.; Reed, T.T.; Venditti, P.; Victor, V.M. Role of ROS and RNS Sources in Physiological and Pathological Conditions. Oxid. Med. Cell. Longev. 2016, 2016, 1245049. [CrossRef] 
24. Holmstrom, K.M.; Finkel, T. Cellular mechanisms and physiological consequences of redox-dependent signalling. Nat. Rev. Mol. Cell Biol. 2014, 15, 411-421. [CrossRef]

25. Ngoi, N.Y.; Liew, A.Q.; Chong, S.J.F.; Davids, M.S.; Clement, M.V.; Pervaiz, S. The redox-senescence axis and its therapeutic targeting. Redox Biol. 2021, 45, 102032. [CrossRef]

26. Davalli, P.; Mitic, T.; Caporali, A.; Lauriola, A.; D'Arca, D. ROS, Cell Senescence, and Novel Molecular Mechanisms in Aging and Age-Related Diseases. Oxid. Med. Cell. Longev. 2016, 2016, 3565127. [CrossRef]

27. Gorgoulis, V.; Adams, P.D.; Alimonti, A.; Bennett, D.C.; Bischof, O.; Bishop, C.; Campisi, J.; Collado, M.; Evangelou, K.; Ferbeyre, G.; et al. Cellular Senescence: Defining a Path Forward. Cell 2019, 179, 813-827. [CrossRef] [PubMed]

28. Passos, J.F.; Nelson, G.; Wang, C.; Richter, T.; Simillion, C.; Proctor, C.J.; Miwa, S.; Olijslagers, S.; Hallinan, J.; Wipat, A.; et al. Feedback between p21 and reactive oxygen production is necessary for cell senescence. Mol. Syst. Biol. 2010, 6, 347. [CrossRef]

29. Nelson, G.; Wordsworth, J.; Wang, C.; Jurk, D.; Lawless, C.; Martin-Ruiz, C.; von Zglinicki, T. A senescent cell bystander effect: Senescence-induced senescence. Aging Cell 2012, 11, 345-349. [CrossRef]

30. Lanigan, F.; Geraghty, J.G.; Bracken, A.P. Transcriptional regulation of cellular senescence. Oncogene 2011, 30, $2901-2911$. [CrossRef] [PubMed]

31. Cheng, L.Q.; Zhang, Z.Q.; Chen, H.Z.; Liu, D.P. Epigenetic regulation in cell senescence. J. Mol. Med. 2017, 95, 1257-1268. [CrossRef] [PubMed]

32. Panda, A.C.; Abdelmohsen, K.; Gorospe, M. SASP regulation by noncoding RNA. Mech. Ageing Dev. 2017, 168, 37-43. [CrossRef] [PubMed]

33. Zhang, P.; Wu, W.; Chen, Q.; Chen, M. Non-Coding RNAs and their Integrated Networks. J. Integr. Bioinform. 2019, 16, 20190027. [CrossRef] [PubMed]

34. Djebali, S.; Davis, C.A.; Merkel, A.; Dobin, A.; Lassmann, T.; Mortazavi, A.; Tanzer, A.; Lagarde, J.; Lin, W.; Schlesinger, F.; et al. Landscape of transcription in human cells. Nature 2012, 489, 101-108. [CrossRef]

35. Bu, H.; Wedel, S.; Cavinato, M.; Jansen-Durr, P. MicroRNA Regulation of Oxidative Stress-Induced Cellular Senescence. Oxid. Med. Cell. Longev. 2017, 2017, 2398696. [CrossRef]

36. Puvvula, P.K. LncRNAs Regulatory Networks in Cellular Senescence. Int. J. Mol. Sci. 2019, 20, 2615. [CrossRef] [PubMed]

37. Ghafouri-Fard, S.; Shoorei, H.; Taheri, M. Non-coding RNAs are involved in the response to oxidative stress. Biomed. Pharmacother. 2020, 127, 110228. [CrossRef] [PubMed]

38. Kim, E.; Kim, Y.K.; Lee, S.V. Emerging functions of circular RNA in aging. Trends Genet. 2021, 37, 819-829. [CrossRef]

39. Hayflick, L.; Moorhead, P.S. The serial cultivation of human diploid cell strains. Exp. Cell Res. 1961, 25, 585-621. [CrossRef]

40. Harley, C.B.; Futcher, A.B.; Greider, C.W. Telomeres shorten during ageing of human fibroblasts. Nature 1990, 345, 458-460. [CrossRef]

41. D'Adda di Fagagna, F.; Reaper, P.M.; Clay-Farrace, L.; Fiegler, H.; Carr, P.; von Zglinicki, T.; Saretzki, G.; Carter, N.P.; Jackson, S.P. A DNA damage checkpoint response in telomere-initiated senescence. Nature 2003, 426, 194-198. [CrossRef] [PubMed]

42. di Micco, R.; Krizhanovsky, V.; Baker, D.; d'Adda di Fagagna, F. Cellular senescence in ageing: From mechanisms to therapeutic opportunities. Nat. Rev. Mol. Cell Biol. 2021, 22, 75-95. [CrossRef] [PubMed]

43. Chen, Q.M.; Bartholomew, J.C.; Campisi, J.; Acosta, M.; Reagan, J.D.; Ames, B.N. Molecular analysis of $\mathrm{H}_{2} \mathrm{O}_{2}$-induced senescentlike growth arrest in normal human fibroblasts: p53 and Rb control G1 arrest but not cell replication. Biochem. J. 1998, 332, 43-50. [CrossRef] [PubMed]

44. Chen, Q.; Ames, B.N. Senescence-like growth arrest induced by hydrogen peroxide in human diploid fibroblast F65 cells. Proc. Natl. Acad. Sci. USA 1994, 91, 4130-4134. [CrossRef] [PubMed]

45. Wiley, C.D.; Velarde, M.C.; Lecot, P.; Liu, S.; Sarnoski, E.A.; Freund, A.; Shirakawa, K.; Lim, H.W.; Davis, S.S.; Ramanathan, A.; et al. Mitochondrial Dysfunction Induces Senescence with a Distinct Secretory Phenotype. Cell Metab. 2016, 23, 303-314. [CrossRef] [PubMed]

46. Passos, J.F.; Saretzki, G.; Ahmed, S.; Nelson, G.; Richter, T.; Peters, H.; Wappler, I.; Birket, M.J.; Harold, G.; Schaeuble, K.; et al. Mitochondrial dysfunction accounts for the stochastic heterogeneity in telomere-dependent senescence. PLoS Biol. 2007, 5, e110. [CrossRef]

47. Kuilman, T.; Michaloglou, C.; Mooi, W.J.; Peeper, D.S. The essence of senescence. Genes Dev. 2010, 24, 2463-2479. [CrossRef] [PubMed]

48. Collado, M.; Serrano, M. Senescence in tumours: Evidence from mice and humans. Nat. Rev. Cancer 2010, 10, 51-57. [CrossRef]

49. Serrano, M.; Lin, A.W.; McCurrach, M.E.; Beach, D.; Lowe, S.W. Oncogenic ras provokes premature cell senescence associated with accumulation of p53 and p16INK4a. Cell 1997, 88, 593-602. [CrossRef]

50. Debacq-Chainiaux, F.; Borlon, C.; Pascal, T.; Royer, V.; Eliaers, F.; Ninane, N.; Carrard, G.; Friguet, B.; de Longueville, F.; Boffe, S.; et al. Repeated exposure of human skin fibroblasts to UVB at subcytotoxic level triggers premature senescence through the TGF-beta1 signaling pathway. J. Cell Sci. 2005, 118, 743-758. [CrossRef]

51. Chainiaux, F.; Magalhaes, J.P.; Eliaers, F.; Remacle, J.; Toussaint, O. UVB-induced premature senescence of human diploid skin fibroblasts. Int. J. Biochem. Cell Biol. 2002, 34, 1331-1339. [CrossRef]

52. Narita, M.; Nunez, S.; Heard, E.; Narita, M.; Lin, A.W.; Hearn, S.A.; Spector, D.L.; Hannon, G.J.; Lowe, S.W. Rb-mediated heterochromatin formation and silencing of E2F target genes during cellular senescence. Cell 2003, 113, 703-716. [CrossRef] 
53. Guillon, J.; Petit, C.; Toutain, B.; Guette, C.; Lelievre, E.; Coqueret, O. Chemotherapy-induced senescence, an adaptive mechanism driving resistance and tumor heterogeneity. Cell Cycle 2019, 18, 2385-2397. [CrossRef]

54. Payea, M.J.; Anerillas, C.; Tharakan, R.; Gorospe, M. Translational Control during Cellular Senescence. Mol. Cell. Biol. 2021, 41, e00512-20. [CrossRef] [PubMed]

55. Ahmed, W.; Lingner, J. Impact of oxidative stress on telomere biology. Differentiation 2018, 99, 21-27. [CrossRef]

56. Hohn, A.; Weber, D.; Jung, T.; Ott, C.; Hugo, M.; Kochlik, B.; Kehm, R.; Konig, J.; Grune, T.; Castro, J.P. Happily (n)ever after: Aging in the context of oxidative stress, proteostasis loss and cellular senescence. Redox Biol. 2017, 11, 482-501. [CrossRef]

57. Lopez-Otin, C.; Blasco, M.A.; Partridge, L.; Serrano, M.; Kroemer, G. The hallmarks of aging. Cell 2013, 153, 1194-1217. [CrossRef]

58. Salama, R.; Sadaie, M.; Hoare, M.; Narita, M. Cellular senescence and its effector programs. Genes Dev. 2014, 28, 99-114. [CrossRef]

59. Kumari, R.; Jat, P. Mechanisms of Cellular Senescence: Cell Cycle Arrest and Senescence Associated Secretory Phenotype. Front. Cell Dev. Biol. 2021, 9, 645593. [CrossRef]

60. Kwon, S.M.; Hong, S.M.; Lee, Y.K.; Min, S.; Yoon, G. Metabolic features and regulation in cell senescence. BMB Rep. 2019, 52, 5-12. [CrossRef]

61. Boumendil, C.; Hari, P.; Olsen, K.C.F.; Acosta, J.C.; Bickmore, W.A. Nuclear pore density controls heterochromatin reorganization during senescence. Genes Dev. 2019, 33, 144-149. [CrossRef] [PubMed]

62. Coppe, J.P.; Patil, C.K.; Rodier, F.; Sun, Y.; Munoz, D.P.; Goldstein, J.; Nelson, P.S.; Desprez, P.Y.; Campisi, J. Senescence-associated secretory phenotypes reveal cell-nonautonomous functions of oncogenic RAS and the p53 tumor suppressor. PLoS Biol. 2008, 6, 2853-2868. [CrossRef] [PubMed]

63. Acosta, J.C.; Banito, A.; Wuestefeld, T.; Georgilis, A.; Janich, P.; Morton, J.P.; Athineos, D.; Kang, T.W.; Lasitschka, F.; Andrulis, M.; et al. A complex secretory program orchestrated by the inflammasome controls paracrine senescence. Nat. Cell Biol. 2013, 15, 978-990. [CrossRef]

64. Barbato, D.L.; Tatulli, G.; Aquilano, K.; Ciriolo, M.R. Inhibition of age-related cytokines production by ATGL: A mechanism linked to the anti-inflammatory effect of resveratrol. Mediat. Inflamm. 2014, 2014, 917698.

65. Lopes-Paciencia, S.; Saint-Germain, E.; Rowell, M.C.; Ruiz, A.F.; Kalegari, P.; Ferbeyre, G. The senescence-associated secretory phenotype and its regulation. Cytokine 2019, 117, 15-22. [CrossRef]

66. Ito, Y.; Hoare, M.; Narita, M. Spatial and Temporal Control of Senescence. Trends Cell Biol. 2017, 27, 820-832. [CrossRef]

67. Yosef, R.; Pilpel, N.; Tokarsky-Amiel, R.; Biran, A.; Ovadya, Y.; Cohen, S.; Vadai, E.; Dassa, L.; Shahar, E.; Condiotti, R.; et al. Directed elimination of senescent cells by inhibition of BCL-W and BCL-XL. Nat. Commun. 2016, 7, 11190. [CrossRef]

68. Misawa, T.; Tanaka, Y.; Okada, R.; Takahashi, A. Biology of extracellular vesicles secreted from senescent cells as senescenceassociated secretory phenotype factors. Geriatr. Gerontol. Int. 2020, 20, 539-546. [CrossRef]

69. Dixon, S.J.; Lemberg, K.M.; Lamprecht, M.R.; Skouta, R.; Zaitsev, E.M.; Gleason, C.E.; Patel, D.N.; Bauer, A.J.; Cantley, A.M.; Yang, W.S.; et al. Ferroptosis: An iron-dependent form of nonapoptotic cell death. Cell 2012, 149, 1060-1072. [CrossRef]

70. Masaldan, S.; Clatworthy, S.A.S.; Gamell, C.; Meggyesy, P.M.; Rigopoulos, A.T.; Haupt, S.; Haupt, Y.; Denoyer, D.; Adlard, P.A.; Bush, A.I.; et al. Iron accumulation in senescent cells is coupled with impaired ferritinophagy and inhibition of ferroptosis. Redox Biol. 2018, 14, 100-115. [CrossRef]

71. Jun, J.I.; Lau, L.F. The matricellular protein CCN1 induces fibroblast senescence and restricts fibrosis in cutaneous wound healing Nat. Cell Biol. 2010, 12, 676-685. [CrossRef]

72. Krizhanovsky, V.; Yon, M.; Dickins, R.A.; Hearn, S.; Simon, J.; Miething, C.; Yee, H.; Zender, L.; Lowe, S.W. Senescence of activated stellate cells limits liver fibrosis. Cell 2008, 134, 657-667. [CrossRef] [PubMed]

73. Mosteiro, L.; Pantoja, C.; Alcazar, N.; Marion, R.M.; Chondronasiou, D.; Rovira, M.; Fernandez-Marcos, P.J.; Munoz-Martin, M.; Blanco-Aparicio, C.; Pastor, J.; et al. Tissue damage and senescence provide critical signals for cellular reprogramming in vivo. Science 2016, 354, aaf4445. [CrossRef] [PubMed]

74. Campisi, J.; Kapahi, P.; Lithgow, G.J.; Melov, S.; Newman, J.C.; Verdin, E. From discoveries in ageing research to therapeutics for healthy ageing. Nature 2019, 571, 183-192. [CrossRef] [PubMed]

75. von Zglinicki, T.; Wan, T.; Miwa, S. Senescence in Post-Mitotic Cells: A Driver of Aging? Antioxid. Redox Signal. 2021, 34, 308-323. [CrossRef]

76. Liu, J.; Ding, Y.; Liu, Z.; Liang, X. Senescence in Mesenchymal Stem Cells: Functional Alterations, Molecular Mechanisms, and Rejuvenation Strategies. Front. Cell Dev. Biol. 2020, 8, 258. [CrossRef]

77. Harman, D. Aging: A theory based on free radical and radiation chemistry. J. Gerontol. 1956, 11, 298-300. [CrossRef]

78. Harman, D. Origin and evolution of the free radical theory of aging: A brief personal history, 1954-2009. Biogerontology 2009, 10, 773-781. [CrossRef]

79. Sies, H. Oxidative stress: A concept in redox biology and medicine. Redox Biol. 2015, 4, 180-183. [CrossRef]

80. Pomatto, L.C.D.; Davies, K.J.A. Adaptive homeostasis and the free radical theory of ageing. Free Radic. Biol. Med. 2018, 124, 420-430. [CrossRef]

81. Ray, P.D.; Huang, B.W.; Tsuji, Y. Reactive oxygen species (ROS) homeostasis and redox regulation in cellular signaling. Cell. Signal. 2012, 24, 981-990. [CrossRef]

82. Sies, H. Oxidative eustress: On constant alert for redox homeostasis. Redox Biol. 2021, 41, 101867. [CrossRef] [PubMed]

83. Balaban, R.S.; Nemoto, S.; Finkel, T. Mitochondria, oxidants, and aging. Cell 2005, 120, 483-495. [CrossRef] [PubMed] 
84. Chandrasekaran, A.; Idelchik, M.D.P.S.; Melendez, J.A. Redox control of senescence and age-related disease. Redox Biol. 2017, 11, 91-102. [CrossRef] [PubMed]

85. Zhang, L.; Wang, X.; Cueto, R.; Effi, C.; Zhang, Y.; Tan, H.; Qin, X.; Ji, Y.; Yang, X.; Wang, H. Biochemical basis and metabolic interplay of redox regulation. Redox Biol. 2019, 26, 101284. [CrossRef]

86. Zhao, R.Z.; Jiang, S.; Zhang, L.; Yu, Z.B. Mitochondrial electron transport chain, ROS generation and uncoupling (Review). Int. J. Mol. Med. 2019, 44, 3-15. [CrossRef]

87. Kodama, R.; Kato, M.; Furuta, S.; Ueno, S.; Zhang, Y.; Matsuno, K.; Yabe-Nishimura, C.; Tanaka, E.; Kamata, T. ROS-generating oxidases Nox1 and Nox4 contribute to oncogenic Ras-induced premature senescence. Genes Cells 2013, 18, 32-41. [CrossRef]

88. Paulsen, C.E.; Carroll, K.S. Cysteine-mediated redox signaling: Chemistry, biology, and tools for discovery. Chem. Rev. 2013, 113, 4633-4679. [CrossRef]

89. Sies, H.; Berndt, C.; Jones, D.P. Oxidative Stress. Annu. Rev. Biochem. 2017, 86, 715-748. [CrossRef]

90. Bagheri, M.; Nair, R.R.; Singh, K.K.; Saini, D.K. ATM-ROS-iNOS axis regulates nitric oxide mediated cellular senescence. Biochim. Biophys. Acta Mol. Cell Res. 2017, 1864, 177-190. [CrossRef]

91. Pourbagher-Shahri, A.M.; Farkhondeh, T.; Talebi, M.; Kopustinskiene, D.M.; Samarghandian, S.; Bernatoniene, J. An Overview of NO Signaling Pathways in Aging. Molecules 2021, 26, 4533. [CrossRef]

92. Chapman, J.; Fielder, E.; Passos, J.F. Mitochondrial dysfunction and cell senescence: Deciphering a complex relationship. FEBS Lett. 2019, 593, 1566-1579. [CrossRef] [PubMed]

93. Zheng, L.; Cardaci, S.; Jerby, L.; MacKenzie, E.D.; Sciacovelli, M.; Johnson, T.I.; Gaude, E.; King, A.; Leach, J.D.; Edrada-Ebel, R.; et al. Fumarate induces redox-dependent senescence by modifying glutathione metabolism. Nat. Commun. 2015, 6, 6001. [CrossRef] [PubMed]

94. Blagosklonny, M.V. Cell senescence and hypermitogenic arrest. EMBO Rep. 2003, 4, 358-362. [CrossRef] [PubMed]

95. Petrova, N.V.; Velichko, A.K.; Razin, S.V.; Kantidze, O.L. Small molecule compounds that induce cellular senescence. Aging Cell 2016, 15, 999-1017. [CrossRef]

96. Shao, L.; Li, H.; Pazhanisamy, S.K.; Meng, A.; Wang, Y.; Zhou, D. Reactive oxygen species and hematopoietic stem cell senescence. Int. J. Hematol. 2011, 94, 24-32. [CrossRef]

97. Mailloux, R.J. An Update on Mitochondrial Reactive Oxygen Species Production. Antioxidants 2020, 9, 472. [CrossRef]

98. Correia-Melo, C.; Marques, F.D.; Anderson, R.; Hewitt, G.; Hewitt, R.; Cole, J.; Carroll, B.M.; Miwa, S.; Birch, J.; Merz, A.; et al Mitochondria are required for pro-ageing features of the senescent phenotype. EMBO J. 2016, 35, 724-742. [CrossRef]

99. Lettieri-Barbato, D.; D’Angelo, F.; Sciarretta, F.; Tatulli, G.; Tortolici, F.; Ciriolo, M.R.; Aquilano, K. Maternal high calorie diet induces mitochondrial dysfunction and senescence phenotype in subcutaneous fat of newborn mice. Oncotarget 2017, 8 83407-83418. [CrossRef]

100. Ziegler, D.V.; Wiley, C.D.; Velarde, M.C. Mitochondrial effectors of cellular senescence: Beyond the free radical theory of aging Aging Cell 2015, 14, 1-7. [CrossRef]

101. Manzella, N.; Santin, Y.; Maggiorani, D.; Martini, H.; Douin-Echinard, V.; Passos, J.F.; Lezoualc'h, F.; Binda, C.; Parini, A.; MialetPerez, J. Monoamine oxidase-A is a novel driver of stress-induced premature senescence through inhibition of parkin-mediated mitophagy. Aging Cell 2018, 17, e12811. [CrossRef]

102. Ahmadinejad, F.; Moller, S.G.; Hashemzadeh-Chaleshtori, M.; Bidkhori, G.; Jami, M.S. Molecular Mechanisms behind Free Radical Scavengers Function against Oxidative Stress. Antioxidants 2017, 6, 51. [CrossRef] [PubMed]

103. Wang, Y.; Branicky, R.; Noe, A.; Hekimi, S. Superoxide dismutases: Dual roles in controlling ROS damage and regulating ROS signaling. J. Cell Biol. 2018, 217, 1915-1928. [CrossRef] [PubMed]

104. Zhang, Y.; Unnikrishnan, A.; Deepa, S.S.; Liu, Y.; Li, Y.; Ikeno, Y.; Sosnowska, D.; van Remmen, H.; Richardson, A. A new role for oxidative stress in aging: The accelerated aging phenotype in Sod1(-/)(-) mice is correlated to increased cellular senescence. Redox Biol. 2017, 11, 30-37. [CrossRef]

105. Kwon, M.J.; Lee, K.Y.; Lee, H.W.; Kim, J.H.; Kim, T.Y. SOD3 Variant, R213G, Altered SOD3 Function, Leading to ROS-Mediated Inflammation and Damage in Multiple Organs of Premature Aging Mice. Antioxid. Redox Signal 2015, 23, 985-999. [CrossRef] [PubMed]

106. Zeida, A.; Trujillo, M.; Ferrer-Sueta, G.; Denicola, A.; Estrin, D.A.; Radi, R. Catalysis of Peroxide Reduction by Fast Reacting Protein Thiols. Chem. Rev. 2019, 119, 10829-10855. [CrossRef] [PubMed]

107. Nandi, A.; Yan, L.J.; Jana, C.K.; Das, N. Role of Catalase in Oxidative Stress- and Age-Associated Degenerative Diseases. Oxid. Med. Cell. Longev. 2019, 2019, 9613090. [CrossRef]

108. De Haan, J.B.; Bladier, C.; Lotfi-Miri, M.; Taylor, J.; Hutchinson, P.; Crack, P.J.; Hertzog, P.; Kola, I. Fibroblasts derived from Gpx1 knockout mice display senescent-like features and are susceptible to $\mathrm{H}_{2} \mathrm{O}_{2}$-mediated cell death. Free Radic. Biol. Med. 2004, 36, 53-64. [CrossRef]

109. Neumann, C.A.; Krause, D.S.; Carman, C.V.; Das, S.; Dubey, D.P.; Abraham, J.L.; Bronson, R.T.; Fujiwara, Y.; Orkin, S.H.; van Etten, R.A. Essential role for the peroxiredoxin Prdx1 in erythrocyte antioxidant defence and tumour suppression. Nature 2003, 424, 561-565. [CrossRef]

110. Aquilano, K.; Baldelli, S.; Ciriolo, M.R. Glutathione: New roles in redox signaling for an old antioxidant. Front. Pharmacol. 2014, 5, 196. [CrossRef] [PubMed] 
111. Sun, Y.; Zheng, Y.; Wang, C.; Liu, Y. Glutathione depletion induces ferroptosis, autophagy, and premature cell senescence in retinal pigment epithelial cells. Cell Death Dis. 2018, 9, 753. [CrossRef]

112. Armeni, T.; Ercolani, L.; Urbanelli, L.; Magini, A.; Magherini, F.; Pugnaloni, A.; Piva, F.; Modesti, A.; Emiliani, C.; Principato, G. Cellular redox imbalance and changes of protein S-glutathionylation patterns are associated with senescence induced by oncogenic H-ras. PLoS ONE 2012, 7, e52151. [CrossRef] [PubMed]

113. Ogata, F.T.; Branco, V.; Vale, F.F.; Coppo, L. Glutaredoxin: Discovery, redox defense and much more. Redox Biol. $2021,43,101975$. [CrossRef] [PubMed]

114. Yang, F.; Yi, M.; Liu, Y.; Wang, Q.; Hu, Y.; Deng, H. Glutaredoxin-1 Silencing Induces Cell Senescence via p53/p21/p16 Signaling Axis. J. Proteome. Res. 2018, 17, 1091-1100. [CrossRef] [PubMed]

115. Monks, T.J.; Lau, S.S. Glutathione conjugation as a mechanism for the transport of reactive metabolites. Adv. Pharmacol. 1994, 27, 183-210. [PubMed]

116. Rizza, S.; Filomeni, G. Chronicles of a reductase: Biochemistry, genetics and physio-pathological role of GSNOR. Free Radic. Biol Med. 2017, 110, 19-30. [CrossRef] [PubMed]

117. Rizza, S.; Cardaci, S.; Montagna, C.; di Giacomo, G.; de Zio, D.; Bordi, M.; Maiani, E.; Campello, S.; Borreca, A.; Puca, A.A.; et al. S-nitrosylation drives cell senescence and aging in mammals by controlling mitochondrial dynamics and mitophagy. Proc. Natl. Acad. Sci. USA 2018, 115, E3388-E3397. [CrossRef]

118. Yuan, H.; Xu, Y.; Luo, Y.; Wang, N.X.; Xiao, J.H. Role of Nrf2 in cell senescence regulation. Mol. Cell. Biochem. 2021, 476, 247-259. [CrossRef] [PubMed]

119. Paladino, S.; Conte, A.; Caggiano, R.; Pierantoni, G.M.; Faraonio, R. Nrf2 Pathway in Age-Related Neurological Disorders: Insights into MicroRNAs. Cell. Physiol. Biochem. 2018, 47, 1951-1976. [CrossRef]

120. Hirotsu, Y.; Katsuoka, F.; Funayama, R.; Nagashima, T.; Nishida, Y.; Nakayama, K.; Engel, J.D.; Yamamoto, M. Nrf2-MafG heterodimers contribute globally to antioxidant and metabolic networks. Nucleic Acids Res. 2012, 40, 10228-10239. [CrossRef] [PubMed]

121. Tebay, L.E.; Robertson, H.; Durant, S.T.; Vitale, S.R.; Penning, T.M.; Dinkova-Kostova, A.T.; Hayes, J.D. Mechanisms of activation of the transcription factor Nrf2 by redox stressors, nutrient cues, and energy status and the pathways through which it attenuates degenerative disease. Free Radic. Biol. Med. 2015, 88, 108-146. [CrossRef]

122. la Rosa, P.; Petrillo, S.; Turchi, R.; Berardinelli, F.; Schirinzi, T.; Vasco, G.; Lettieri-Barbato, D.; Fiorenza, M.T.; Bertini, E.S.; Aquilano, K.; et al. The Nrf2 induction prevents ferroptosis in Friedreich's Ataxia. Redox Biol. 2021, 38, 101791. [CrossRef] [PubMed]

123. Bailey-Downs, L.C.; Mitschelen, M.; Sosnowska, D.; Toth, P.; Pinto, J.T.; Ballabh, P.; Valcarcel-Ares, M.N.; Farley, J.; Koller, A.; Henthorn, J.C.; et al. Liver-specific knockdown of IGF-1 decreases vascular oxidative stress resistance by impairing the Nrf2-dependent antioxidant response: A novel model of vascular aging. J. Gerontol. A Biol. Sci. Med. Sci. 2012, 67, 313-329. [CrossRef] [PubMed]

124. Ogrunc, M.; di Micco, R.; Liontos, M.; Bombardelli, L.; Mione, M.; Fumagalli, M.; Gorgoulis, V.G.; d'Adda di Fagagna, F. Oncogene-induced reactive oxygen species fuel hyperproliferation and DNA damage response activation. Cell Death Differ. 2014, 21, 998-1012. [CrossRef]

125. Schreck, R.; Rieber, P.; Baeuerle, P.A. Reactive oxygen intermediates as apparently widely used messengers in the activation of the NF-kappa B transcription factor and HIV-1. EMBO J. 1991, 10, 2247-2258. [CrossRef] [PubMed]

126. Rodier, F.; Coppe, J.P.; Patil, C.K.; Hoeijmakers, W.A.; Munoz, D.P.; Raza, S.R.; Freund, A.; Campeau, E.; Davalos, A.R.; Campisi, J. Persistent DNA damage signalling triggers senescence-associated inflammatory cytokine secretion. Nat. Cell Biol. 2009, 11, 973-979. [CrossRef]

127. Freund, A.; Patil, C.K.; Campisi, J. p38MAPK is a novel DNA damage response-independent regulator of the senescence-associated secretory phenotype. EMBO J. 2011, 30, 1536-1548. [CrossRef] [PubMed]

128. Chien, Y.; Scuoppo, C.; Wang, X.; Fang, X.; Balgley, B.; Bolden, J.E.; Premsrirut, P.; Luo, W.; Chicas, A.; Lee, C.S.; et al. Control of the senescence-associated secretory phenotype by NF-kappaB promotes senescence and enhances chemosensitivity. Genes Dev. 2011, 25, 2125-2136. [CrossRef] [PubMed]

129. Tilstra, J.S.; Robinson, A.R.; Wang, J.; Gregg, S.Q.; Clauson, C.L.; Reay, D.P.; Nasto, L.A.; Croix, C.M.S.; Usas, A.; Vo, N.; et al. NF-kappaB inhibition delays DNA damage-induced senescence and aging in mice. J. Clin. Investig. 2012, 122, $2601-2612$. [CrossRef] [PubMed]

130. Cuadrado, A.; Manda, G.; Hassan, A.; Alcaraz, M.J.; Barbas, C.; Daiber, A.; Ghezzi, P.; Leon, R.; Lopez, M.G.; Oliva, B. Transcription Factor NRF2 as a Therapeutic Target for Chronic Diseases: A Systems Medicine Approach. Pharmacol. Rev. 2018, 70, 348-383. [CrossRef] [PubMed]

131. Jones, R.G.; Plas, D.R.; Kubek, S.; Buzzai, M.; Mu, J.; Xu, Y.; Birnbaum, M.J.; Thompson, C.B. AMP-activated protein kinase induces a p53-dependent metabolic checkpoint. Mol. Cell 2005, 18, 283-293. [CrossRef] [PubMed]

132. Peyton, K.J.; Liu, X.M.; Yu, Y.; Yates, B.; Durante, W. Activation of AMP-activated protein kinase inhibits the proliferation of human endothelial cells. J. Pharmacol. Exp. Ther. 2012, 342, 827-834. [CrossRef]

133. Covarrubias, A.J.; Perrone, R.; Grozio, A.; Verdin, E. NAD(+) metabolism and its roles in cellular processes during ageing. Nat. Rev. Mol. Cell Biol. 2021, 22, 119-141.

134. Ma, C.; Pi, C.; Yang, Y.; Lin, L.; Shi, Y.; Li, Y.; Li, Y.; He, X. Nampt Expression Decreases Age-Related Senescence in Rat Bone Marrow Mesenchymal Stem Cells by Targeting Sirt1. PLoS ONE 2017, 12, e0170930. [CrossRef] 
135. Luna, A.; Aladjem, M.I.; Kohn, K.W. SIRT1/PARP1 crosstalk: Connecting DNA damage and metabolism. Genome Integr. 2013, 4, 6. [CrossRef] [PubMed]

136. Langley, E.; Pearson, M.; Faretta, M.; Bauer, U.M.; Frye, R.A.; Minucci, S.; Pelicci, P.G.; Kouzarides, T. Human SIR2 deacetylates p53 and antagonizes PML/p53-induced cellular senescence. EMBO J. 2002, 21, 2383-2396. [CrossRef] [PubMed]

137. Osborne, B.; Bentley, N.L.; Montgomery, M.K.; Turner, N. The role of mitochondrial sirtuins in health and disease. Free Radic. Biol. Med. 2016, 100, 164-174. [CrossRef] [PubMed]

138. Kong, X.; Wang, R.; Xue, Y.; Liu, X.; Zhang, H.; Chen, Y.; Fang, F.; Chang, Y. Sirtuin 3, a new target of PGC-1alpha, plays an important role in the suppression of ROS and mitochondrial biogenesis. PLoS ONE 2010, 5, e11707. [CrossRef] [PubMed]

139. Gomes, A.P.; Price, N.L.; Ling, A.J.; Moslehi, J.J.; Montgomery, M.K.; Rajman, L.; White, J.P.; Teodoro, J.S.; Wrann, C.D.; Hubbard, B.P.; et al. Declining $\mathrm{NAD}(+)$ induces a pseudohypoxic state disrupting nuclear-mitochondrial communication during aging. Cell 2013, 155, 1624-1638. [CrossRef]

140. Mouchiroud, L.; Houtkooper, R.H.; Moullan, N.; Katsyuba, E.; Ryu, D.; Canto, C.; Mottis, A.; Jo, Y.S.; Viswanathan, M.; Schoonjans, $\mathrm{K} . ;$ et al. The $\mathrm{NAD}(+)$ /Sirtuin Pathway Modulates Longevity through Activation of Mitochondrial UPR and FOXO Signaling. Cell 2013, 154, 430-441. [CrossRef] [PubMed]

141. Barbato, D.L.; Tatulli, G.; Aquilano, K.; Ciriolo, M.R. Mitochondrial Hormesis links nutrient restriction to improved metabolism in fat cell. Aging 2015, 7, 869-881. [CrossRef] [PubMed]

142. Storz, P. Forkhead homeobox type O transcription factors in the responses to oxidative stress. Antioxid. Redox Signal. 2011, 14, 593-605. [CrossRef] [PubMed]

143. Bourgeois, B.; Madl, T. Regulation of cellular senescence via the FOXO4-p53 axis. FEBS Lett. 2018, 592, 2083-2097. [CrossRef] [PubMed]

144. Barbato, D.L.; Tatulli, G.; Vegliante, R.; Cannata, S.M.; Bernardini, S.; Ciriolo, M.R.; Aquilano, K. Dietary fat overload reprograms brown fat mitochondria. Front. Physiol. 2015, 6, 272.

145. Sun, N.; Youle, R.J.; Finkel, T. The Mitochondrial Basis of Aging. Mol. Cell 2016, 61, 654-666. [CrossRef]

146. Miyauchi, H.; Minamino, T.; Tateno, K.; Kunieda, T.; Toko, H.; Komuro, I. Akt negatively regulates the in vitro lifespan of human endothelial cells via a p53/p21-dependent pathway. EMBO J. 2004, 23, 212-220. [CrossRef]

147. Nogueira, V.; Park, Y.; Chen, C.C.; Xu, P.Z.; Chen, M.L.; Tonic, I.; Unterman, T.; Hay, N. Akt determines replicative senescence and oxidative or oncogenic premature senescence and sensitizes cells to oxidative apoptosis. Cancer Cell 2008, 14, 458-470. [CrossRef]

148. Li, M.; Chiu, J.F.; Mossman, B.T.; Fukagawa, N.K. Down-regulation of manganese-superoxide dismutase through phosphorylation of FOXO3a by Akt in explanted vascular smooth muscle cells from old rats. J. Biol. Chem. 2006, 281, 40429-40439. [CrossRef] [PubMed]

149. De Keizer, P.L.; Packer, L.M.; Szypowska, A.A.; Riedl-Polderman, P.E.; van den Broek, N.J.; de Bruin, A.; Dansen, T.B.; Marais, R.; Brenkman, A.B.; Burgering, B.M. Activation of forkhead box O transcription factors by oncogenic BRAF promotes p21cip1dependent senescence. Cancer Res. 2010, 70, 8526-8536. [CrossRef]

150. Vizioli, M.G.; Liu, T.; Miller, K.N.; Robertson, N.A.; Gilroy, K.; Lagnado, A.B.; Perez-Garcia, A.; Kiourtis, C.; Dasgupta, N.; Lei, X.; et al. Mitochondria-to-nucleus retrograde signaling drives formation of cytoplasmic chromatin and inflammation in senescence. Genes Dev. 2020, 34, 428-445. [CrossRef] [PubMed]

151. Li, S.K.; Smith, D.K.; Leung, W.Y.; Cheung, A.M.; Lam, E.W.; Dimri, G.P.; Yao, K.M. FoxM1c counteracts oxidative stress-induced senescence and stimulates Bmi-1 expression. J. Biol. Chem. 2008, 283, 16545-16553. [CrossRef] [PubMed]

152. Zhu, X.; Chen, Z.; Shen, W.; Huang, G.; Sedivy, J.M.; Wang, H.; Ju, Z. Inflammation, epigenetics, and metabolism converge to cell senescence and ageing: The regulation and intervention. Signal Transduct. Target Ther. 2021, 6, 245. [CrossRef] [PubMed]

153. Jung, Y.D.; Park, S.K.; Kang, D.; Hwang, S.; Kang, M.H.; Hong, S.W.; Moon, J.H.; Shin, J.S.; Jin, D.H.; You, D.; et al. Epigenetic regulation of miR-29a/miR-30c/DNMT3A axis controls SOD2 and mitochondrial oxidative stress in human mesenchymal stem cells. Redox Biol. 2020, 37, 101716. [CrossRef] [PubMed]

154. He, Y.F.; Li, B.Z.; Li, Z.; Liu, P.; Wang, Y.; Tang, Q.; Ding, J.; Jia, Y.; Chen, Z.; Li, L.; et al. Tet-mediated formation of 5carboxylcytosine and its excision by TDG in mammalian DNA. Science 2011, 333, 1303-1307. [CrossRef]

155. Kietzmann, T.; Petry, A.; Shvetsova, A.; Gerhold, J.M.; Gorlach, A. The epigenetic landscape related to reactive oxygen species formation in the cardiovascular system. Br. J. Pharmacol. 2017, 174, 1533-1554. [CrossRef]

156. Sasaki, M.; Kajiya, H.; Ozeki, S.; Okabe, K.; Ikebe, T. Reactive oxygen species promotes cellular senescence in normal human epidermal keratinocytes through epigenetic regulation of p16(INK4a.). Biochem. Biophys. Res. Commun. 2014, 452, 622-628. [CrossRef]

157. Jung, H.J.; Byun, H.O.; Jee, B.A.; Min, S.; Jeoun, U.W.; Lee, Y.K.; Seo, Y.; Woo, H.G.; Yoon, G. The Ubiquitin-like with PHD and Ring Finger Domains 1 (UHRF1)/DNA Methyltransferase 1 (DNMT1) Axis Is a Primary Regulator of Cell Senescence. J. Biol. Chem. 2017, 292, 3729-3739. [CrossRef]

158. Sidler, C.; Kovalchuk, O.; Kovalchuk, I. Epigenetic Regulation of Cellular Senescence and Aging. Front. Genet. 2017, 8, 138. [CrossRef]

159. Unnikrishnan, A.; Freeman, W.M.; Jackson, J.; Wren, J.D.; Porter, H.; Richardson, A. The role of DNA methylation in epigenetics of aging. Pharmacol. Ther. 2019, 195, 172-185. [CrossRef] 
160. Mahmoud, A.M.; Wilkinson, F.L.; Sandhu, M.A.; Santos, J.M.D.; Alexander, M.Y. Modulating Oxidative Stress in Drug-Induced Injury and Metabolic Disorders: The Role of Natural and Synthetic Antioxidants. Oxid. Med. Cell. Longev. 2019, $2019,3206401$. [CrossRef]

161. Lee, S.H.; Lee, J.H.; Lee, H.Y.; Min, K.J. Sirtuin signaling in cellular senescence and aging. BMB Rep. 2019, 52, 24-34. [CrossRef] [PubMed]

162. Piunti, A.; Rossi, A.; Cerutti, A.; Albert, M.; Jammula, S.; Scelfo, A.; Cedrone, L.; Fragola, G.; Olsson, L.; Koseki, H.; et al. Polycomb proteins control proliferation and transformation independently of cell cycle checkpoints by regulating DNA replication. Nat. Commun. 2014, 5, 3649. [CrossRef] [PubMed]

163. Liu, C.; Liu, L.; Yang, M.; Li, B.; Yi, J.; Ai, X.; Zhang, Y.; Huang, B.; Li, C.; Feng, C.; et al. A positive feedback loop between EZH2 and NOX4 regulates nucleus pulposus cell senescence in age-related intervertebral disc degeneration. Cell Div. 2020, 15, 2. [CrossRef]

164. Bracken, A.P.; Kleine-Kohlbrecher, D.; Dietrich, N.; Pasini, D.; Gargiulo, G.; Beekman, C.; Theilgaard-Monch, K.; Minucci, S.; Porse, B.T.; Marine, J.C.; et al. The Polycomb group proteins bind throughout the INK4A-ARF locus and are disassociated in senescent cells. Genes Dev. 2007, 21, 525-530. [CrossRef] [PubMed]

165. Shah, P.P.; Donahue, G.; Otte, G.L.; Capell, B.C.; Nelson, D.M.; Cao, K.; Aggarwala, V.; Cruickshanks, H.A.; Rai, T.S.; McBryan, T.; et al. Lamin B1 depletion in senescent cells triggers large-scale changes in gene expression and the chromatin landscape. Genes Dev. 2013, 27, 1787-1799. [CrossRef] [PubMed]

166. Kosar, M.; Bartkova, J.; Hubackova, S.; Hodny, Z.; Lukas, J.; Bartek, J. Senescence-associated heterochromatin foci are dispensable for cellular senescence, occur in a cell type- and insult-dependent manner and follow expression of p16(ink4a). Cell Cycle 2011, 10, 457-468. [CrossRef] [PubMed]

167. Aquilano, K.; Ceci, V.; Gismondi, A.; de Stefano, S.; Iacovelli, F.; Faraonio, R.; di Marco, G.; Poerio, N.; Minutolo, A.; Minopoli, G.; et al. Adipocyte metabolism is improved by TNF receptor-targeting small RNAs identified from dried nuts. Commun. Biol. 2019, 2, 317. [CrossRef]

168. Stefani, G.; Slack, F.J. Small non-coding RNAs in animal development. Nat. Rev. Mol. Cell Biol. 2008, 9, 219-230. [CrossRef]

169. Pasquinelli, A.E. MicroRNAs and their targets: Recognition, regulation and an emerging reciprocal relationship. Nat. Rev. Genet. 2012, 13, 271-282. [CrossRef]

170. Grillari, J.; Grillari-Voglauer, R. Novel modulators of senescence, aging, and longevity: Small non-coding RNAs enter the stage. Exp. Gerontol. 2010, 45, 302-311. [CrossRef]

171. Sayed, D.; Abdellatif, M. MicroRNAs in development and disease. Physiol. Rev. 2011, 91, 827-887. [CrossRef] [PubMed]

172. Quiat, D.; Olson, E.N. MicroRNAs in cardiovascular disease: From pathogenesis to prevention and treatment. J. Clin. Investig. 2013, 123, 11-18. [CrossRef] [PubMed]

173. Croce, C.M. Causes and consequences of microRNA dysregulation in cancer. Nat. Rev. Genet. 2009, 10, 704-714. [CrossRef] [PubMed]

174. Almeida, R.; Allshire, R.C. RNA silencing and genome regulation. Trends Cell Biol. 2005, 15, 251-258. [CrossRef]

175. Lytle, J.R.; Yario, T.A.; Steitz, J.A. Target mRNAs are repressed as efficiently by microRNA-binding sites in the $5^{\prime}$ UTR as in the $3^{\prime}$ UTR. Proc. Natl. Acad. Sci. USA 2007, 104, 9667-9672. [CrossRef]

176. Bartel, D.P. MicroRNAs: Target recognition and regulatory functions. Cell 2009, 136, 215-233. [CrossRef]

177. Leung, A.K.; Calabrese, J.M.; Sharp, P.A. Quantitative analysis of Argonaute protein reveals microRNA-dependent localization to stress granules. Proc. Natl. Acad. Sci. USA 2006, 103, 18125-18130. [CrossRef]

178. Leung, A.K.; Sharp, P.A. microRNAs: A safeguard against turmoil? Cell 2007, 130, 581-585. [CrossRef]

179. Siow, R.C.; Forman, H.J. Redox regulation of microRNAs in health and disease. Free Radic. Biol. Med. 2013, 64, 1-3. [CrossRef]

180. Zhang, C.; Shu, L.; Kong, A.N. MicroRNAs: New players in cancer prevention targeting Nrf2, oxidative stress and inflammatory pathways. Curr. Pharmacol. Rep. 2015, 1, 21-30. [CrossRef]

181. Li, G.; Luna, C.; Qiu, J.; Epstein, D.L.; Gonzalez, P. Alterations in microRNA expression in stress-induced cellular senescence. Mech. Ageing Dev. 2009, 130, 731-741. [CrossRef] [PubMed]

182. Liu, Y.; Qiang, W.; Xu, X.; Dong, R.; Karst, A.M.; Liu, Z.; Kong, B.; Drapkin, R.I.; Wei, J.J. Role of miR-182 in response to oxidative stress in the cell fate of human fallopian tube epithelial cells. Oncotarget 2015, 6, 38983-38998. [CrossRef] [PubMed]

183. Weeraratne, S.D.; Amani, V.; Teider, N.; Pierre-Francois, J.; Winter, D.; Kye, M.J.; Sengupta, S.; Archer, T.; Remke, M.; Bai, A.H.; et al. Pleiotropic effects of miR-183 96 182 converge to regulate cell survival, proliferation and migration in medulloblastoma. Acta Neuropathol. 2012, 123, 539-552. [CrossRef] [PubMed]

184. Krishnan, K.; Steptoe, A.L.; Martin, H.C.; Wani, S.; Nones, K.; Waddell, N.; Mariasegaram, M.; Simpson, P.T.; Lakhani, S.R.; Gabrielli, B.; et al. MicroRNA-182-5p targets a network of genes involved in DNA repair. RNA 2013, 19, 230-242. [CrossRef]

185. Hackl, M.; Brunner, S.; Fortschegger, K.; Schreiner, C.; Micutkova, L.; Muck, C.; Laschober, G.T.; Lepperdinger, G.; Sampson, N.; Berger, P.; et al. miR-17, miR-19b, miR-20a, and miR-106a are down-regulated in human aging. Aging Cell 2010, 9, 291-296. [CrossRef] [PubMed]

186. Tai, L.; Huang, C.J.; Choo, K.B.; Cheong, S.K.; Kamarul, T. Oxidative Stress Down-Regulates MiR-20b-5p, MiR-106a-5p and E2F1 Expression to Suppress the G1/S Transition of the Cell Cycle in Multipotent Stromal Cells. Int. J. Med. Sci. 2020, 17, 457-470. [CrossRef] 
187. Magenta, A.; Cencioni, C.; Fasanaro, P.; Zaccagnini, G.; Greco, S.; Sarra-Ferraris, G.; Antonini, A.; Martelli, F.; Capogrossi, M.C. miR-200c is upregulated by oxidative stress and induces endothelial cell apoptosis and senescence via ZEB1 inhibition. Cell Death Differ. 2011, 18, 1628-1639. [CrossRef] [PubMed]

188. Carlomosti, F.; D’Agostino, M.; Beji, S.; Torcinaro, A.; Rizzi, R.; Zaccagnini, G.; Maimone, B.; di Stefano, V.; de Santa, F.; Cordisco, S.; et al. Oxidative Stress-Induced miR-200c Disrupts the Regulatory Loop Among SIRT1, FOXO1, and eNOS. Antioxid. Redox Signal. 2017, 27, 328-344. [CrossRef]

189. Xiao, Y.; Yan, W.; Lu, L.; Wang, Y.; Lu, W.; Cao, Y.; Cai, W. p38/p53/miR-200a-3p feedback loop promotes oxidative stress-mediated liver cell death. Cell Cycle 2015, 14, 1548-1558. [CrossRef] [PubMed]

190. Dimri, M.; Carroll, J.D.; Cho, J.H.; Dimri, G.P. microRNA-141 regulates BMI1 expression and induces senescence in human diploid fibroblasts. Cell Cycle 2013, 12, 3537-3546. [CrossRef]

191. Park, I.K.; Morrison, S.J.; Clarke, M.F. Bmi1, stem cells, and senescence regulation. J. Clin. Investig. 2004, 113, 175-179. [CrossRef] [PubMed]

192. Bhaumik, D.; Scott, G.K.; Schokrpur, S.; Patil, C.K.; Orjalo, A.V.; Rodier, F.; Lithgow, G.J.; Campisi, J. MicroRNAs miR-146a/b negatively modulate the senescence-associated inflammatory mediators IL-6 and IL-8. Aging 2009, 1, 402-411. [CrossRef]

193. Taganov, K.D.; Boldin, M.P.; Chang, K.J.; Baltimore, D. NF-kappaB-dependent induction of microRNA miR-146, an inhibitor targeted to signaling proteins of innate immune responses. Proc. Natl. Acad. Sci. USA 2006, 103, 12481-12486. [CrossRef] [PubMed]

194. Cheng, H.S.; Sivachandran, N.; Lau, A.; Boudreau, E.; Zhao, J.L.; Baltimore, D.; Delgado-Olguin, P.; Cybulsky, M.I.; Fish, J.E. MicroRNA-146 represses endothelial activation by inhibiting pro-inflammatory pathways. EMBO Mol. Med. 2013, 5, 1017-1034. [CrossRef] [PubMed]

195. Smith, E.J.; Shay, K.P.; Thomas, N.O.; Butler, J.A.; Finlay, L.F.; Hagen, T.M. Age-related loss of hepatic Nrf2 protein homeostasis: Potential role for heightened expression of miR-146a. Free Radic. Biol. Med. 2015, 89, 1184-1191. [CrossRef] [PubMed]

196. Okada, M.; Kim, H.W.; Matsu-ura, K.; Wang, Y.G.; Xu, M.; Ashraf, M. Abrogation of Age-Induced MicroRNA-195 Rejuvenates the Senescent Mesenchymal Stem Cells by Reactivating Telomerase. Stem. Cells 2016, 34, 148-159. [CrossRef]

197. Xu, M.; Su, X.; Xiao, X.; Yu, H.; Li, X.; Keating, A.; Wang, S.; Zhao, R.C. Hydrogen Peroxide-Induced Senescence Reduces the Wound Healing-Promoting Effects of Mesenchymal Stem Cell-Derived Exosomes Partially via miR-146a. Aging Dis. 2021, 12, 102-115. [CrossRef]

198. Liu, X.; Yang, Z.; Meng, Q.; Chen, Y.; Shao, L.; Li, J.; Chen, Y.; Shen, Z. Downregulation of MicroRNA-206 Alleviates the Sublethal Oxidative Stress-Induced Premature Senescence and Dysfunction in Mesenchymal Stem Cells via Targeting Alpl. Oxid. Med. Cell. Longev. 2020, 2020, 7242836. [CrossRef]

199. Kim, J.Y.; Park, Y.K.; Lee, K.P.; Lee, S.M.; Kang, T.W.; Kim, H.J.; Dho, S.H.; Kim, S.Y.; Kwon, K.S. Genome-wide profiling of the microRNA-mRNA regulatory network in skeletal muscle with aging. Aging 2014, 6, 524-544. [CrossRef]

200. Sangokoya, C.; Telen, M.J.; Chi, J.T. microRNA miR-144 modulates oxidative stress tolerance and associates with anemia severity in sickle cell disease. Blood 2010, 116, 4338-4348. [CrossRef]

201. Mercken, E.M.; Majounie, E.; Ding, J.; Guo, R.; Kim, J.; Bernier, M.; Mattison, J.; Cookson, M.R.; Gorospe, M.; de Cabo, R.; et al. Age-associated miRNA alterations in skeletal muscle from rhesus monkeys reversed by caloric restriction. Aging 2013, 5, 692-703. [CrossRef] [PubMed]

202. Le, M.T.; Teh, C.; Shyh-Chang, N.; Xie, H.; Zhou, B.; Korzh, V.; Lodish, H.F.; Lim, B. MicroRNA-125b is a novel negative regulator of p53. Genes Dev. 2009, 23, 862-876. [CrossRef]

203. Faraonio, R.; Vergara, P.; di Marzo, D.; Pierantoni, M.G.; Napolitano, M.; Russo, T.; Cimino, F. p53 suppresses the Nrf2-dependent transcription of antioxidant response genes. J. Biol. Chem. 2006, 281, 39776-39784. [CrossRef] [PubMed]

204. Bai, X.Y.; Ma, Y.; Ding, R.; Fu, B.; Shi, S.; Chen, X.M. miR-335 and miR-34a Promote renal senescence by suppressing mitochondrial antioxidative enzymes. J. Am. Soc. Nephrol. 2011, 22, 1252-1261. [CrossRef] [PubMed]

205. Li, N.; Muthusamy, S.; Liang, R.; Sarojini, H.; Wang, E. Increased expression of miR-34a and miR-93 in rat liver during aging, and their impact on the expression of Mgst1 and Sirt1. Mech. Ageing Dev. 2011, 132, 75-85. [CrossRef] [PubMed]

206. Ito, T.; Yagi, S.; Yamakuchi, M. MicroRNA-34a regulation of endothelial senescence. Biochem. Biophys. Res. Commun. 2010, 398, 735-740. [CrossRef] [PubMed]

207. Tabuchi, T.; Satoh, M.; Itoh, T.; Nakamura, M. MicroRNA-34a regulates the longevity-associated protein SIRT1 in coronary artery disease: Effect of statins on SIRT1 and microRNA-34a expression. Clin. Sci. 2012, 123, 161-171. [CrossRef] [PubMed]

208. Lamoke, F.; Shaw, S.; Yuan, J.; Ananth, S.; Duncan, M.; Martin, P.; Bartoli, M. Increased Oxidative and Nitrative Stress Accelerates Aging of the Retinal Vasculature in the Diabetic Retina. PLoS ONE 2015, 10, e0139664. [CrossRef] [PubMed]

209. Baker, J.R.; Vuppusetty, C.; Colley, T.; Papaioannou, A.I.; Fenwick, P.; Donnelly, L.; Ito, K.; Barnes, P.J. Oxidative stress dependent microRNA-34a activation via PI3Kalpha reduces the expression of sirtuin-1 and sirtuin-6 in epithelial cells. Sci. Rep. 2016, 6, 35871. [CrossRef] [PubMed]

210. He, L.; He, X.; Lim, L.P.; de Stanchina, E.; Xuan, Z.; Liang, Y.; Xue, W.; Zender, L.; Magnus, J.; Ridzon, D.; et al. A microRNA component of the p53 tumour suppressor network. Nature 2007, 447, 1130-1134. [CrossRef]

211. Hermeking, H. The miR-34 family in cancer and apoptosis. Cell Death Differ. 2010, 17, 193-199. [CrossRef] [PubMed] 
212. Choi, S.E.; Fu, T.; Seok, S.; Kim, D.H.; Yu, E.; Lee, K.W.; Kang, Y.; Li, X.; Kemper, B.; Kemper, J.K. Elevated microRNA-34a in obesity reduces NAD ${ }^{+}$levels and SIRT1 activity by directly targeting NAMPT. Aging Cell 2013, 12, 1062-1072. [CrossRef] [PubMed]

213. Kim, Y.J.; Hwang, S.H.; Lee, S.Y.; Shin, K.K.; Cho, H.H.; Bae, Y.C.; Jung, J.S. miR-486-5p induces replicative senescence of human adipose tissue-derived mesenchymal stem cells and its expression is controlled by high glucose. Stem Cells Dev. 2012, 21, 1749-1760. [CrossRef] [PubMed]

214. Faraonio, R.; Salerno, P.; Passaro, F.; Sedia, C.; Iaccio, A.; Bellelli, R.; Nappi, T.C.; Comegna, M.; Romano, S.; Salvatore, G.; et al. A set of miRNAs participates in the cellular senescence program in human diploid fibroblasts. Cell Death Differ. 2012, 19, 713-721. [CrossRef] [PubMed]

215. Baker, J.R.; Vuppusetty, C.; Colley, T.; Hassibi, S.; Fenwick, P.S.; Donnelly, L.E.; Ito, K.; Barnes, P.J. MicroRNA-570 is a novel regulator of cellular senescence and inflammaging. FASEB J. 2019, 33, 1605-1616. [CrossRef] [PubMed]

216. Menghini, R.; Casagrande, V.; Cardellini, M.; Martelli, E.; Terrinoni, A.; Amati, F.; Vasa-Nicotera, M.; Ippoliti, A.; Novelli, G.; Melino, G.; et al. MicroRNA 217 modulates endothelial cell senescence via silent information regulator 1. Circulation 2009, 120, 1524-1532. [CrossRef] [PubMed]

217. Wang, B.; Du, R.; Xiao, X.; Deng, Z.L.; Jian, D.; Xie, H.F.; Li, J. Microrna-217 modulates human skin fibroblast senescence by directly targeting DNA methyltransferase 1. Oncotarget 2017, 8, 33475-33486. [CrossRef] [PubMed]

218. Mensa, E.; Guescini, M.; Giuliani, A.; Bacalini, M.G.; Ramini, D.; Corleone, G.; Ferracin, M.; Fulgenzi, G.; Graciotti, L.; Prattichizzo, F.; et al. Small extracellular vesicles deliver miR-21 and miR-217 as pro-senescence effectors to endothelial cells. J. Extracell. Vesicles 2020, 9, 1725285. [CrossRef]

219. Heid, J.; Cencioni, C.; Ripa, R.; Baumgart, M.; Atlante, S.; Milano, G.; Scopece, A.; Kuenne, C.; Guenther, S.; Azzimato, V.; et al. Age-dependent increase of oxidative stress regulates microRNA-29 family preserving cardiac health. Sci. Rep. 2017, 7, 16839. [CrossRef] [PubMed]

220. Hu, Z.; Klein, J.D.; Mitch, W.E.; Zhang, L.; Martinez, I.; Wang, X.H. MicroRNA-29 induces cellular senescence in aging muscle through multiple signaling pathways. Aging 2014, 6, 160-175. [CrossRef]

221. Fenn, A.M.; Smith, K.M.; Lovett-Racke, A.E.; Guerau-de-Arellano, M.; Whitacre, C.C.; Godbout, J.P. Increased micro-RNA 29b in the aged brain correlates with the reduction of insulin-like growth factor-1 and fractalkine ligand. Neurobiol. Aging 2013, 34, 2748-2758. [CrossRef] [PubMed]

222. Ugalde, A.P.; Ramsay, A.J.; de la Rosa, J.; Varela, I.; Marino, G.; Cadinanos, J.; Lu, J.; Freije, J.M.; Lopez-Otin, C. Aging and chronic DNA damage response activate a regulatory pathway involving miR-29 and p53. EMBO J. 2011, 30, 2219-2232. [CrossRef] [PubMed]

223. Ripa, R.; Dolfi, L.; Terrigno, M.; Pandolfini, L.; Savino, A.; Arcucci, V.; Groth, M.; Tozzini, E.T.; Baumgart, M.; Cellerino, A MicroRNA miR-29 controls a compensatory response to limit neuronal iron accumulation during adult life and aging. BMC Biol. 2017, 15, 9. [CrossRef] [PubMed]

224. Wang, Y.; Scheiber, M.N.; Neumann, C.; Calin, G.A.; Zhou, D. MicroRNA regulation of ionizing radiation-induced premature senescence. Int. J. Radiat. Oncol. Biol. Phys. 2011, 81, 839-848. [CrossRef] [PubMed]

225. Onodera, Y.; Teramura, T.; Takehara, T.; Obora, K.; Mori, T.; Fukuda, K. miR-155 induces ROS generation through downregulation of antioxidation-related genes in mesenchymal stem cells. Aging Cell 2017, 16, 1369-1380. [CrossRef]

226. Oh, J.; Lee, Y.D.; Wagers, A.J. Stem cell aging: Mechanisms, regulators and therapeutic opportunities. Nat. Med. 2014, 20, 870-880. [CrossRef]

227. Geiger, J.; Dalgaard, L.T. Interplay of mitochondrial metabolism and microRNAs. Cell. Mol. Life Sci. 2017, 74, 631-646. [CrossRef] [PubMed]

228. Yamamoto, H.; Morino, K.; Nishio, Y.; Ugi, S.; Yoshizaki, T.; Kashiwagi, A.; Maegawa, H. MicroRNA-494 regulates mitochondrial biogenesis in skeletal muscle through mitochondrial transcription factor A and Forkhead box j3. Am. J. Physiol. Endocrinol. Metab. 2012, 303, E1419-E1427. [CrossRef] [PubMed]

229. Liu, Y.; Li, X.; Zhu, S.; Zhang, J.G.; Yang, M.; Qin, Q.; Deng, S.C.; Wang, B.; Tian, K.; Liu, L.; et al. Ectopic expression of miR-494 inhibited the proliferation, invasion and chemoresistance of pancreatic cancer by regulating SIRT1 and c-Myc. Gene Ther. 2015, 22, 729-738. [CrossRef]

230. Xiong, R.; Wang, Z.; Zhao, Z.; Li, H.; Chen, W.; Zhang, B.; Wang, L.; Wu, L.; Li, W.; Ding, J.; et al. MicroRNA-494 reduces DJ-1 expression and exacerbates neurodegeneration. Neurobiol. Aging 2014, 35, 705-714. [CrossRef]

231. Lemecha, M.; Morino, K.; Imamura, T.; Iwasaki, H.; Ohashi, N.; Ida, S.; Sato, D.; Sekine, O.; Ugi, S.; Maegawa, H. MiR-494-3p regulates mitochondrial biogenesis and thermogenesis through PGC1-alpha signalling in beige adipocytes. Sci. Rep. 2018, 8, 15096. [CrossRef]

232. Espinosa-Diez, C.; Wilson, R.; Chatterjee, N.; Hudson, C.; Ruhl, R.; Hipfinger, C.; Helms, E.; Khan, O.F.; Anderson, D.G.; Anand, S. MicroRNA regulation of the MRN complex impacts DNA damage, cellular senescence, and angiogenic signaling. Cell Death Dis. 2018, 9, 632. [CrossRef] [PubMed]

233. Comegna, M.; Succoio, M.; Napolitano, M.; Vitale, M.; D’Ambrosio, C.; Scaloni, A.; Passaro, F.; Zambrano, N.; Cimino, F.; Faraonio, R. Identification of miR-494 direct targets involved in senescence of human diploid fibroblasts. FASEB J. 2014, 28, 3720-3733. [CrossRef] [PubMed] 
234. Venkataraman, S.; Alimova, I.; Fan, R.; Harris, P.; Foreman, N.; Vibhakar, R. MicroRNA 128a increases intracellular ROS level by targeting Bmi-1 and inhibits medulloblastoma cancer cell growth by promoting senescence. PLoS ONE 2010, 5, e10748. [CrossRef] [PubMed]

235. Liu, J.; Cao, L.; Chen, J.; Song, S.; Lee, I.H.; Quijano, C.; Liu, H.; Keyvanfar, K.; Chen, H.; Cao, L.Y.; et al. Bmi1 regulates mitochondrial function and the DNA damage response pathway. Nature 2009, 459, 387-392. [CrossRef]

236. Lian, B.; Yang, D.; Liu, Y.; Shi, G.; Li, J.; Yan, X.; Jin, K.; Liu, X.; Zhao, J.; Shang, W.; et al. miR-128 Targets the SIRT1/ROS/DR5 Pathway to Sensitize Colorectal Cancer to TRAIL-Induced Apoptosis. Cell. Physiol. Biochem. 2018, 49, 2151-2162. [CrossRef] [PubMed]

237. Caggiano, R.; Cattaneo, F.; Moltedo, O.; Esposito, G.; Perrino, C.; Trimarco, B.; Ammendola, R.; Faraonio, R. miR-128 Is Implicated in Stress Responses by Targeting MAFG in Skeletal Muscle Cells. Oxid. Med. Cell. Longev. 2017, 2017, 9308310. [CrossRef]

238. Guo, J.; Xiao, F.; Ren, W.; Zhu, Y.; Du, Q.; Li, Q.; Li, X. Circular Ribonucleic Acid circFTO Promotes Angiogenesis and Impairs Blood-Retinal Barrier Via Targeting the miR-128-3p/Thioredoxin Interacting Protein Axis in Diabetic Retinopathy. Front. Mol. Biosci. 2021, 8, 685466. [CrossRef]

239. Lang, A.; Grether-Beck, S.; Singh, M.; Kuck, F.; Jakob, S.; Kefalas, A.; Altinoluk-Hambuchen, S.; Graffmann, N.; Schneider, M.; Lindecke, A.; et al. MicroRNA-15b regulates mitochondrial ROS production and the senescence-associated secretory phenotype through sirtuin 4/SIRT4. Aging 2016, 8, 484-505. [CrossRef] [PubMed]

240. Chen, Z.; Li, Y.; Zhang, H.; Huang, P.; Luthra, R. Hypoxia-regulated microRNA-210 modulates mitochondrial function and decreases ISCU and COX10 expression. Oncogene 2010, 29, 4362-4368. [CrossRef]

241. Puissegur, M.P.; Mazure, N.M.; Bertero, T.; Pradelli, L.; Grosso, S.; Robbe-Sermesant, K.; Maurin, T.; Lebrigand, K.; Cardinaud, B.; Hofman, V.; et al. miR-210 is overexpressed in late stages of lung cancer and mediates mitochondrial alterations associated with modulation of HIF-1 activity. Cell Death Differ. 2011, 18, 465-478. [CrossRef] [PubMed]

242. Overhoff, M.G.; Garbe, J.C.; Koh, J.; Stampfer, M.R.; Beach, D.H.; Bishop, C.L. Cellular senescence mediated by p16INK4A-coupled miRNA pathways. Nucleic. Acids Res. 2014, 42, 1606-1618. [CrossRef]

243. Maes, O.C.; Sarojini, H.; Wang, E. Stepwise up-regulation of microRNA expression levels from replicating to reversible and irreversible growth arrest states in WI-38 human fibroblasts. J. Cell Physiol. 2009, 221, 109-119. [CrossRef]

244. Hu, W.; Xu, S.; Yao, B.; Hong, M.; Wu, X.; Pei, H.; Chang, L.; Ding, N.; Gao, X.; Ye, C.; et al. MiR-663 inhibits radiation-induced bystander effects by targeting TGFB1 in a feedback mode. RNA Biol. 2014, 11, 1189-1198. [CrossRef] [PubMed]

245. Huang, Y.; Liu, J.; Fan, L.; Wang, F.; Yu, H.; Wei, W.; Sun, G. miR-663 overexpression induced by endoplasmic reticulum stress modulates hepatocellular carcinoma cell apoptosis via transforming growth factor beta 1. Onco. Targets Ther. 2016, 9, 1623-1633. [CrossRef]

246. Carden, T.; Singh, B.; Mooga, V.; Bajpai, P.; Singh, K.K. Epigenetic modification of miR-663 controls mitochondria-to-nucleus retrograde signaling and tumor progression. J. Biol. Chem. 2017, 292, 20694-20706. [CrossRef]

247. Huang, Y.; He, Y.; Li, J. MicroRNA-21: A central regulator of fibrotic diseases via various targets. Curr. Pharm. Des. 2015, 21, 2236-2242. [CrossRef] [PubMed]

248. Hinkel, R.; Ramanujam, D.; Kaczmarek, V.; Howe, A.; Klett, K.; Beck, C.; Dueck, A.; Thum, T.; Laugwitz, K.L.; Maegdefessel, L.; et al. AntimiR-21 Prevents Myocardial Dysfunction in a Pig Model of Ischemia/Reperfusion Injury. J. Am. Coll. Cardiol. 2020, 75, 1788-1800. [CrossRef] [PubMed]

249. Olivieri, F.; Capri, M.; Bonafe, M.; Morsiani, C.; Jung, H.J.; Spazzafumo, L.; Vina, J.; Suh, Y. Circulating miRNAs and miRNA shuttles as biomarkers: Perspective trajectories of healthy and unhealthy aging. Mech. Ageing Dev. 2017, 165, 162-170. [CrossRef] [PubMed]

250. Jazbutyte, V.; Fiedler, J.; Kneitz, S.; Galuppo, P.; Just, A.; Holzmann, A.; Bauersachs, J.; Thum, T. MicroRNA-22 increases senescence and activates cardiac fibroblasts in the aging heart. Age 2013, 35, 747-762. [CrossRef]

251. Liu, Z.; Li, T.; Zhu, F.; Deng, S.; Li, X.; He, Y. Regulatory roles of miR-22/Redd1-mediated mitochondrial ROS and cellular autophagy in ionizing radiation-induced BMSC injury. Cell Death Dis. 2019, 10, 227. [CrossRef] [PubMed]

252. Yao, R.W.; Wang, Y.; Chen, L.L. Cellular functions of long noncoding RNAs. Nat. Cell Biol. 2019, 21, 542-551. [CrossRef]

253. Gamez-Valero, A.; Guisado-Corcoll, A.; Herrero-Lorenzo, M.; Solaguren-Beascoa, M.; Marti, E. Non-Coding RNAs as Sensors of Oxidative Stress in Neurodegenerative Diseases. Antioxidants 2020, 9, 1095. [CrossRef] [PubMed]

254. Wang, X.; Shen, C.; Zhu, J.; Shen, G.; Li, Z.; Dong, J. Long Noncoding RNAs in the Regulation of Oxidative Stress. Oxid. Med. Cell. Longev. 2019, 2019, 1318795. [CrossRef]

255. He, J.; Tu, C.; Liu, Y. Role of lncRNAs in aging and age-related diseases. Aging Med. 2018, 1, 158-175. [CrossRef] [PubMed]

256. Yap, K.L.; Li, S.; Munoz-Cabello, A.M.; Raguz, S.; Zeng, L.; Mujtaba, S.; Gil, J.; Walsh, M.J.; Zhou, M.M. Molecular interplay of the noncoding RNA ANRIL and methylated histone H3 lysine 27 by polycomb CBX7 in transcriptional silencing of INK4a. Mol. Cell 2010, 38, 662-674. [CrossRef]

257. Abdelmohsen, K.; Panda, A.; Kang, M.J.; Xu, J.; Selimyan, R.; Yoon, J.H.; Martindale, J.L.; De, S.; Wood, W.H., III; Becker, K.G.; et al. Senescence-associated lncRNAs: Senescence-associated long noncoding RNAs. Aging Cell 2013, 12, 890-900. [CrossRef]

258. Zeng, R.; Zhang, R.; Song, X.; Ni, L.; Lai, Z.; Liu, C.; Ye, W. The long non-coding RNA MALAT1 activates Nrf2 signaling to protect human umbilical vein endothelial cells from hydrogen peroxide. Biochem. Biophys. Res. Commun. 2018, 495, 2532-2538. [CrossRef] 
259. Amodio, N.; Stamato, M.A.; Juli, G.; Morelli, E.; Fulciniti, M.; Manzoni, M.; Taiana, E.; Agnelli, L.; Cantafio, M.E.G.; Romeo, E.; et al. Drugging the lncRNA MALAT1 via LNA gapmeR ASO inhibits gene expression of proteasome subunits and triggers anti-multiple myeloma activity. Leukemia 2018, 32, 1948-1957. [CrossRef]

260. Yu, J.; Chen, L.H.; Zhang, B.; Zheng, Q.M. The modulation of endometriosis by lncRNA MALAT1 via NF-kappaB/iNOS. Eur. Rev. Med. Pharmacol. Sci. 2019, 23, 4073-4080.

261. Gong, W.; Zhu, G.; Li, J.; Yang, X. LncRNA MALAT1 promotes the apoptosis and oxidative stress of human lens epithelial cells via p38MAPK pathway in diabetic cataract. Diabetes Res. Clin. Pract. 2018, 144, 314-321. [CrossRef] [PubMed]

262. Zhao, L.; Hu, K.; Cao, J.; Wang, P.; Li, J.; Zeng, K.; He, X.; Tu, P.F.; Tong, T.; Han, L. lncRNA miat functions as a ceRNA to upregulate sirt1 by sponging miR-22-3p in HCC cellular senescence. Aging 2019, 11, 7098-7122. [CrossRef] [PubMed]

263. Tay, Y.; Rinn, J.; Pandolfi, P.P. The multilayered complexity of ceRNA crosstalk and competition. Nature 2014, 505, 344-352. [CrossRef] [PubMed]

264. Wang, X.; Zou, M.; Li, J.; Wang, B.; Zhang, Q.; Liu, F.; Lu, G. LncRNA H19 targets miR-22 to modulate $\mathrm{H}_{2} \mathrm{O}_{2}$-induced deregulation in nucleus pulposus cell senescence, proliferation, and ECM synthesis through Wnt signaling. J. Cell. Biochem. 2018, 119, 4990-5002. [CrossRef]

265. Zhuang, Y.; Li, T.; Xiao, H.; Wu, J.; Su, S.; Dong, X.; Hu, X.; Hua, Q.; Liu, J.; Shang, W.; et al. LncRNA-H19 Drives Cardiomyocyte Senescence by Targeting miR-19a/socs1/p53 Axis. Front. Pharmacol. 2021, 12, 631835. [CrossRef]

266. Hofmann, P.; Sommer, J.; Theodorou, K.; Kirchhof, L.; Fischer, A.; Li, Y.; Perisic, L.; Hedin, U.; Maegdefessel, L.; Dimmeler, S.; et al. Long non-coding RNA H19 regulates endothelial cell aging via inhibition of STAT3 signalling. Cardiovasc. Res. 2019, 115, 230-242. [CrossRef]

267. Imig, J.; Brunschweiger, A.; Brummer, A.; Guennewig, B.; Mittal, N.; Kishore, S.; Tsikrika, P.; Gerber, A.P.; Zavolan, M.; Hall, J. miR-CLIP capture of a miRNA targetome uncovers a lincRNA H19-miR-106a interaction. Nat. Chem. Biol. 2015, 11, 107-114. [CrossRef]

268. Aguilo, F.; Zhou, M.M.; Walsh, M.J. Long noncoding RNA, polycomb, and the ghosts haunting INK4b-ARF-INK4a expression. Cancer Res. 2011, 71, 5365-5369. [CrossRef]

269. Tan, P.; Guo, Y.H.; Zhan, J.K.; Long, L.M.; Xu, M.L.; Ye, L.; Ma, X.Y.; Cui, X.J.; Wang, H.Q. LncRNA-ANRIL inhibits cell senescence of vascular smooth muscle cells by regulating miR-181a/Sirt1. Biochem. Cell Biol. 2019, 97, 571-580. [CrossRef]

270. Du, S.; Shao, J.; Qi, Y.; Liu, X.; Liu, J.; Zhang, F. Long non-coding RNA ANRIL alleviates $\mathrm{H}_{2} \mathrm{O}_{2}$-induced injury by up-regulating microRNA-21 in human lens epithelial cells. Aging 2020, 12, 6543-6557. [CrossRef]

271. Ozes, A.R.; Miller, D.F.; Ozes, O.N.; Fang, F.; Liu, Y.; Matei, D.; Huang, T.; Nephew, K.P. NF-kappaB-HOTAIR axis links DNA damage response, chemoresistance and cellular senescence in ovarian cancer. Oncogene 2016, 35, 5350-5361. [CrossRef]

272. Yoon, J.H.; Abdelmohsen, K.; Kim, J.; Yang, X.; Martindale, J.L.; Tominaga-Yamanaka, K.; White, E.J.; Orjalo, A.V.; Rinn, J.L.; Kreft, S.G.; et al. Scaffold function of long non-coding RNA HOTAIR in protein ubiquitination. Nat. Commun. 2013, 4, 2939. [CrossRef] [PubMed]

273. Li, L.; Zhang, M.; Chen, W.; Wang, R.; Ye, Z.; Wang, Y.; Li, X.; Cai, C. LncRNA-HOTAIR inhibition aggravates oxidative stress-induced H9c2 cells injury through suppression of MMP2 by miR-125. Acta Biochim. Biophys. Sin. 2018, 50, 996-1006. [CrossRef] [PubMed]

274. Zhan, S.; Wang, K.; Song, Y.; Li, S.; Yin, H.; Luo, R.; Liao, Z.; Wu, X.; Zhang, Y.; Yang, C. Long non-coding RNA HOTAIR modulates intervertebral disc degenerative changes via Wnt/beta-catenin pathway. Arthritis Res. Ther. 2019, 21, 201. [CrossRef] [PubMed]

275. Puvvula, P.K.; Desetty, R.D.; Pineau, P.; Marchio, A.; Moon, A.; Dejean, A.; Bischof, O. Long noncoding RNA PANDA and scaffold-attachment-factor SAFA control senescence entry and exit. Nat. Commun. 2014, 5, 5323. [CrossRef]

276. Xia, W.; Zhuang, L.; Deng, X.; Hou, M. Long noncoding RNAp21 modulates cellular senescence via the Wnt/betacatenin signaling pathway in mesenchymal stem cells. Mol. Med. Rep. 2017, 16, 7039-7047. [CrossRef]

277. Florian, M.C.; Nattamai, K.J.; Dorr, K.; Marka, G.; Uberle, B.; Vas, V.; Eckl, C.; Andra, I.; Schiemann, M.; Oostendorp, R.A.; et al. A canonical to non-canonical Wnt signalling switch in haematopoietic stem-cell ageing. Nature 2013, 503, 392-396. [CrossRef]

278. Dimitrova, N.; Zamudio, J.R.; Jong, R.M.; Soukup, D.; Resnick, R.; Sarma, K.; Ward, A.J.; Raj, A.; Lee, J.T.; Sharp, P.A.; et al. LincRNA-p21 activates p21 in cis to promote Polycomb target gene expression and to enforce the G1/S checkpoint. Mol. Cell 2014, 54, 777-790. [CrossRef]

279. Kumar, P.P.; Emechebe, U.; Smith, R.; Franklin, S.; Moore, B.; Yandell, M.; Lessnick, S.L.; Moon, A.M. Coordinated control of senescence by lncRNA and a novel T-box3 co-repressor complex. Elife 2014, 3, e02805. [CrossRef]

280. Lazorthes, S.; Vallot, C.; Briois, S.; Aguirrebengoa, M.; Thuret, J.Y.; Laurent, G.S.; Rougeulle, C.; Kapranov, P.; Mann, C.; Trouche, D.; et al. A vlincRNA participates in senescence maintenance by relieving H2AZ-mediated repression at the INK4 locus. Nat. Commun. 2015, 6, 5971. [CrossRef]

281. Leiper, J.; Nandi, M.; Torondel, B.; Murray-Rust, J.; Malaki, M.; O’Hara, B.; Rossiter, S.; Anthony, S.; Madhani, M.; Selwood, D.; et al. Disruption of methylarginine metabolism impairs vascular homeostasis. Nat. Med. 2007, 13, 198-203. [CrossRef]

282. Jeck, W.R.; Sharpless, N.E. Detecting and characterizing circular RNAs. Nat. Biotechnol. 2014, 32, 453-461. [CrossRef] [PubMed]

283. Li, X.; Yang, L.; Chen, L.L. The Biogenesis, Functions, and Challenges of Circular RNAs. Mol. Cell 2018, 71, 428-442. [CrossRef] [PubMed] 
284. Kristensen, L.S.; Andersen, M.S.; Stagsted, L.V.W.; Ebbesen, K.K.; Hansen, T.B.; Kjems, J. The biogenesis, biology and characterization of circular RNAs. Nat. Rev. Genet. 2019, 20, 675-691. [CrossRef]

285. Panda, A.C.; Grammatikakis, I.; Kim, K.M.; De, S.; Martindale, J.L.; Munk, R.; Yang, X.; Abdelmohsen, K.; Gorospe, M. Identification of senescence-associated circular RNAs (SAC-RNAs) reveals senescence suppressor CircPVT1. Nucleic. Acids Res. 2017, 45, 4021-4035. [CrossRef] [PubMed]

286. Du, W.W.; Yang, W.; Chen, Y.; Wu, Z.K.; Foster, F.S.; Yang, Z.; Li, X.; Yang, B.B. Foxo3 circular RNA promotes cardiac senescence by modulating multiple factors associated with stress and senescence responses. Eur. Heart J. 2017, 38, 1402-1412. [CrossRef] [PubMed]

287. Yu, A.Q.; Wang, Z.X.; Wu, W.; Chen, K.Y.; Yan, S.R.; Mao, Z.B. Circular RNA CircCCNB1 sponges micro RNA-449a to inhibit cellular senescence by targeting CCNE2. Aging 2019, 11, 10220-10241. [CrossRef]

288. Wu, W.P.; Zhou, M.Y.; Liu, D.L.; Min, X.; Shao, T.; Xu, Z.Y.; Jing, X.; Cai, M.Y.; Xu, S.; Liang, X.; et al. CircGNAQ, a circular RNA enriched in vascular endothelium, inhibits endothelial cell senescence and atherosclerosis progression. Mol. Ther. Nucleic. Acids 2021, 26, 374-387. [CrossRef]

289. Xie, L.; Huang, W.; Fang, Z.; Ding, F.; Zou, F.; Ma, X.; Tao, J.; Guo, J.; Xia, X.; Wang, H.; et al. CircERCC2 ameliorated intervertebral disc degeneration by regulating mitophagy and apoptosis through miR-182-5p/SIRT1 axis. Cell Death Dis. 2019, 10, 751. [CrossRef] 